\title{
Andrea Pozzo and the Jesuit "Theatres" of the Seventeenth Century
}

\author{
Andrew Horn \\ University of Edinburgh, School of History of Art \\ Andrew.Horn@ed.ac.uk
}

\begin{abstract}
Considered within the context of Jesuit theatre and liturgy, and within the broader culture of spectacle and ritual in the era of Counter-Reform, the works of art and architecture commissioned by the Jesuits in the seventeenth century can be read as "theatres" of religious performance. This concept is given an ideal case study in the work of Jesuit artist Andrea Pozzo (1642-1709). In this essay I present Pozzo's work within the context of ritual and prayer for which it was produced, focusing on two of his religious scenographies and two of his lesser-known painting projects. As I consider their use of allegory, emblems and symbols, visual narratives, spatial illusions, and architecture, I argue that both the scenographies and the permanent church decorations achieve persuasion through the engagement of the observer as a performer in a ritual involving both internal and external performance.
\end{abstract}

\section{Keywords}

Jesuit - Andrea Pozzo - baroque - illusionism - theatre - spectacle - scenography painting

Although it is an established overarching theme in studies of early modern culture, "theatricality" is a topic which has only recently received the kind of focused and detailed treatment needed to make it a useful framework for the art and architecture of the sixteenth and seventeenth centuries. ${ }^{1}$ The Jesuits have

1 Recent work in this area includes Genevieve Warwick, Bernini: Art as Theatre (New Haven: Yale University Press, 2012); Performativity and Performance in Baroque Rome, ed. Peter

(C) ANDREW HORN, 2019 | DOI:10.1163/22141332-00602003

This is an open access article distributed under the terms of the prevailing CC-BY-NC license at the time of publication. 
long been recognized for their important role in the development of the theatrical religious culture of Italy during the period of the Counter-Reformation. Jesuit theatre took a wide variety of forms, including the mounting of theatrical productions in the colleges and the courts, as well as the design and staging of major urban festivals and religious devotions-all seen as effective tools of religious and often political persuasion. In her work on early modern Jesuit culture and education in Milan, Giovanna Zanlonghi has presented the theory of a complex strategy of performance and visual spectacle comprising word, gesture, and image; a complete system of performed communication to which she has applied the term "total rhetoric."2 Studying Jesuit works of art and architecture in the seventeenth century alongside the ephemeral creations which the Society produced for theatrical performances, religious devotions and other types of spectacle, we find correspondence not only in their design, but in their ritual function. Visual rhetoric and theatre, typically studied separately within the field of Jesuit cultural and historical studies, can and should be considered together in the light of a broader strategy created by the Society to produce a level of persuasion probably not achievable by a single medium; and the key to this persuasion lies in performance. Zanlonghi's theory can be applied not only to scenographies, but to the permanent works of art and architecture produced by the Jesuits which act as settings for performances, and at the same time perform. Seen through this lens, these works, structures and spaces serve not only as the locus of religious theatre, the setting for ritual, but as religious theatre. This idea is given an ideal case study in the work of Jesuit artist, architect and scenographer Andrea Pozzo (1642-1709).

Pozzo is best known for his extraordinary painted illusionism; indeed nearly all of the anglophone scholarship on Pozzo has centered on his perspective practice. ${ }^{3}$ In my upcoming monograph on Pozzo I make the point that the

Gillgren and Mårten Snickare (London: Routledge, 2012); and Theatricality in Early Modern Art and Architecture, ed. Caroline van Eck and Stijn Bussels (Chichester: Wiley-Blackwell, 2011). For an example survey of theatricality in baroque architecture, see, among others, Gordon Dotson, J. B. Fischer von Erlach: Architecture as Theater in the Baroque Era (New Haven: Yale University Press, 2012). An earlier study which raised the theme of theatricality and urbanism in the seventeenth century is the well-known survey by Richard Krautheimer, The Rome of Alexander VII (Princeton: Princeton University Press, 1986).

2 See Giovanna Zanlonghi, Teatri diformazione: Actio, parola e immagine nella scena gesuitica del Sei-Settecento a Milano (Milan: Vita e Pensiero, 2002), 201-4; and "The Jesuit Stage and Theatre in Milan during the Eighteenth Century," in The Jesuits II: Cultures, Sciences and the Arts, 1540-1773, ed. John W. O'Malley, S.J., et al. (Toronto: University of Toronto Press, 2006), $530-49$, here 538 .

3 Wittkower's remarks on Pozzo in 1958 limit his achievement, and his contribution to the perspectival art of the age, to technique and scale. Wittkower, Art and Architecture in Italy 
perspectival illusionism for which he is so well-known is not necessarily ground-breaking in its technique, nor is it a major development on the established practices and theories it draws upon. ${ }^{4}$ In his treatise on perspective Pozzo employs methods which had been established by previous generations of artists and writers of perspective treatises. In Italy, he built upon the work of artists, architects and theoreticians including Sebastiano Serlio (1475-c.1554), Giacomo Barozzi da Vignola (1507-73), Guidobaldo del Monte (1545-1607), and Gian Paolo Lomazzo (1538-92). ${ }^{5}$ France had its own tradition of research and publication on perspective; treatises from the middle of the century by the Jesuit Jean Dubreuil (1602-70) and Abraham Bosse (1604-76) very likely served as the methodological basis for a number of Pozzo's projects. ${ }^{6}$ In his application of perspective to illusionistic frescoes on walls and ceilings, Pozzo was preceded by a long

1600-1750 (Middlesex: Penguin, 1973), 334. Martin Kemp analyses Pozzo's perspective system, his defense of it, as well as the meanings and intellectual context surrounding it in "Perspective and Meaning: Illusion, Allusion, and Collusion," in Philosophy and the Visual Arts: Seeing and Abstracting, ed. Andrew Harrison (Dordrecht: D. Reidel, 1987), 255-68; and Kemp, The Science of Art: Optical Themes in Western Art from Brunelleschi to Seurat (New Haven: Yale University Press, 1990), 137-40. The recent translation of Felix Burda-Stengel's Andrea Pozzo and Video Art (Philadelphia: Saint Joseph's University Press, 2013), originally Andrea Pozzo und die Videokunst: Neue Überlegungen zum barocken Illusionismus (Berlin: Mann, 2001), is the first publication in English to offer more lengthy visual analyses of Pozzo's major works of perspectival illusionism, including San Francesco Saverio at Mondovi, the Corridor of Saint Ignatius in the Casa Professa in Rome, and the fresco works and fictive cupola in Sant'Ignazio.

4 Andrew Horn, Andrea Pozzo and the Religious Theatre of the Seventeenth Century, Early Modern Catholicism and the Visual Arts, vol. 18 (Philadelphia: Saint Joseph's University Press, 2019). The present essay is an introduction and overview of the research to appear in more expanded form in this forthcoming volume.

5 Major Italian treatises on perspective include Leon Battista Alberti, On Painting (De pictura, 1435); Serlio, Regole generali d'architettura (1537, 1545); Piero della Francesca, De prospectiva pingendi (1474); Vignola, Le due regole della prospettiva pratica (1583); Daniele Barbaro, La pratica della prospettiva (1568), Lomazzo (Trattato dell'arte della pittura, scoltura et architettura (1583), and Guidobaldo del Monte, Perspectivae libri sex (1600). Vignola, whom Pozzo cites in several places in his treatise, describes the rendering of overhead perspective scenes on vaults, including curved vaults.

6 In France, Viator Jean Pèlerin developed a method of bifocal or two-point perspective in $D e$ artificiali perspectiva: Pinceaux, burins, acuilles, lices, pierres, bois metaulx, artifice (Toul, 1505, 1509); in the seventeenth century Abraham Bosse extended the theories of Girard Desargues to problems including irregular surfaces and vaults in Moyen universel de pratiquer la perspective sur les tableaux ou surfaces irrégulières (Paris: Bosse, 1653). Jean Dubreuil developed such methods for many applications for anamorphoses as well as the design of illusionistic domes and other architectural features in La Perspective pratique, necessaire a tous peintres, graveurs, sculpteurs, architectes, orfeures, brodeurs, tapissiers, \& autres se servans du Dessein, 3 parts (Paris: Tavernier, 1642 [Part I], 1647 [Part II ], 1649 [Part III]). 
tradition in Bologna and the Po region, derived from the perfected quadratura techniques of Raphael (1480-1520), expanded by Baldassare Peruzzi (1481-1536) and carried north by Giulio Romano. ${ }^{7}$ Notable examples in Genoa, where Pozzo spent time in the early 1670 , include the work of Andrea Ansaldo (1584-1638), Giulio Benso (1592-1668), and Giovanni Battista Carlone $(c .1603-84){ }^{8}$

Although it is true that Pozzo practiced perspective on a scale and a level of precision that is nearly unsurpassed in art, his real contribution lies in the function of his perspectival images and systems within specific contexts, and in their relationship to the observer. In the examination of Pozzo, we need to look beyond his perspective practice, and even the subject of illusionism, and consider their function as components of a larger system which includes both visual rhetoric and performance. I argue that in Pozzo's works, both the scenographies and the permanent church decorations, persuasion is achieved not only through visual rhetoric or visual effects, but through the interaction of the observer with these images and effects: he or she is actively engaged as a performer. ${ }^{9}$ In order to qualify this reading, of course, we must consider these works within their ritual settings, in which the observer is involved as a participant in a sacred rite or religious narrative. I will begin this inquiry by briefly tracing the development of Pozzo's scenographic practice within the context of Jesuit education and culture, and within the broader culture of seventeenthcentury performance and spectacle, starting with his early period in Milan and continuing in Rome. With these frameworks in mind, I will offer case studies of two of his major scenographies, with the principle aim of identifying in specific terms the relationship of the scenographies to the rituals for which they were made. I will then offer similar contextual analyses of two of his

7 See Martin Kemp's overview of the history of perspective practice and theory: Kemp, The Science of Art, 69-72.

8 Many authors have recognized the correspondence between the work of these Genoese quadraturists and Pozzo's painting work and perspective technique. See Giuseppe Dardanello, "Esperienze e opere in Piemonte e Liguria," in Andrea Pozzo, ed. Vittorio De Feo and Valentino Martinelli (Milan: Electa, 1996), 24-41; here 27; and Claudio Strinati, "Gli affreschi nella chiesa di Sant'Ignazio a Roma," 66-93 in the same volume. Benso's fresco series The Stories of the Virgin (1640-44) decorating the vault of the presbytery in the church of the Santissima Annunziata del Vastato is a tour de force of figures and architectural perspectival illusionism which anticipates the complexity and theatricality of Pozzo's major fresco projects. For examples of Genoese quadratura, see Marzia Cataldi Gallo et al., Valerio Castello 1624-1659: Genio moderno, exh. cat., Museo di Palazzo Reale, Teatro del Falcone, February 15-June 15, 2008 (Milan: Skira, 2008).

9 This is the central argument of my aforementioned forthcoming volume on Pozzo. 
lesser-studied fresco cycles: the church of San Francesco Saverio at Mondovì, and the Corridor of Saint Ignatius in the Casa Professa of the Gesù in Rome.

Rhetoric and performance were central features of the Jesuits' educational system: the various editions of the Ratio studiorum published between 1586 and 1599 indicate the engagement of students in rhetorical activities of a wide variety, ranging from the composition of emblems, epitaphs and imprese (image-text devices associated with a person or event) to the delivery of poems and dialogues in the classroom, to the performance of fully-produced dramatic works at the time of the annual awards. ${ }^{10}$ In the Ratio of 1586 , theatrical presentations are described as a means by which both young men and their parents were "delighted" and "set aflame," and at the same time were bound closer to the Society, as students showcased their rhetorical achievements. ${ }^{11}$ Jesuit theatre sought to achieve such persuasion not only through the use of words and the performance of the texts, but also through images, the representation of locales, and visual effects. Maciej Kazimierz Sarbiewski (1595-1640), resident at the Collegio Romano from 1622 to 1625 , produced a treatise on theatre, De perfecta poesi, sive Vergilius et Homerus (1626), in which he describes performance as consisting not only in the spoken word, but in gesture, emotion, "melody," machines, and "apparatus." ${ }^{2}$ Physical production-including the stage facility, lighting, costumes, scene changes and stage effects—is described by Sarbiewski not merely as the means of augmenting performance, increasing

10 See St. Ignatius and the Ratio studiorum, ed. Edward A. Fitzpatrick, trans. Mary Helen Mayer and A. R. Ball (New York: McGraw-Hill, 1933). From the Ratio studiorum of 1599, "Rules of the Academy of Rhetoricians and Students of Humanities," 3. The Exercises to Be Held by the Members, 251: "they will compose emblems, escutcheons, on certain definite matters; again they will write inscriptions and descriptions." Similar rhetorical activities, as well as the writing and performance of plays, appear in the Ratio studiorum of 1586 and 1591. See Ratio studiorum: Ratio atque institutio studiorum Societatis Iesu, in Monumenta Historica Societatis Iesu, ed. Ladislaus Lukács S.I., vol. 129. Monumenta Paedagogica Societatis Iesu, 5 (Rome: Institutum Historicum Societatis Iesu, 1986).

11 Ratio studiorum (1586), "De studiis humanitatis," chap. 7. "Adolescentes tandem eorumque parentes mirifice exhilarantur atque accendantur." See John W. O’Malley, S.J., The First Jesuits (Cambridge, MA: Harvard University Press, 1993), 222; and Bruna Filippi, "Il teatro al Collegio Romano: Dal testo drammatico al contesto scenico," in I gesuiti e i primordi del teatro barocco in Europa: XVIII Convegno Internazionale, ed. Maria Chiabò and Federico Doglio (Rome: Centro Studi sul Teatro Medioevale e Rinascimentale, 1994), 161-82; here 174 .

12 Maciej Kazimierz Sarbiewski, De perfecta poesi, sive Vergilius et Homerus, 1619-1626 (Wrocław: Zakład imienia Ossolińskich Wydawnictwo Polskiej Akademii Nauk, 1954), Book IX, Chapters III-VI, 231 [462]-234 [468]. 
its credibility or intensifying audience response, but as an intrinsic part of this performance; an essential part of the overall rhetorical system of Jesuit theatre.

Jesuit stage production developed to a high level of technical sophistication by the mid-seventeenth century, as demonstrated in the 1649 edition of La perspective pratique by Jean Dubreuil which includes an extensive section dedicated to stage scenography. ${ }^{13}$ Jesuit productions were lavish affairs, as evidenced in surviving accounts and programs, involving multiple changes of scene and "miraculous" events which took place before the audience. ${ }^{14}$ The integration of the arts and the engagement of the observer in a multimedia, multi-sensory experience is a core theory in baroque studies, particularly in examinations of Gian Lorenzo Bernini (1598-1680). ${ }^{15}$ In the Jesuit theatre, and in Jesuit art and architecture, such fusion of the arts, and the performative engagement of the observer in such a rhetorical system, could be said to appeal to the emotions in a way which surpasses the persuasive potential of any of the arts individually.

Born and raised in Trent, Andrea Pozzo was educated by the Jesuits before turning to painting, and later joined the Society in Milan in $1665 .{ }^{16}$ Beginning in his childhood in Trent, Pozzo would have been witness to spectacles marking important public events, from the entrances of rulers and bishops to state funerals. ${ }^{17}$ Pozzo's studies at the Jesuit college at Trent included the humanities and

13 Dubreuil, La perspective pratique, Traité IV, 92-104.

14 A large collection of argomenti of Jesuit productions at the Seminario Romano is held at the Biblioteca Casanatense, Rome: vol. misc. 2013 9, vol. misc. 1731, and vol. misc. 1118.

15 This idea is first studied at length in relation to Bernini in Irving Lavin, Bernini and the Unity of the Visual Arts, 2 vols. (New York: Oxford University Press, 1980); and given further examination with a particular emphasis on performance in Warwick, Bernini: Art as Theatre. The theory of uniting the arts of architecture, sculpture and painting into a bel composto appears in the biographies of Bernini, for example in Filippo Baldinucci, The Life of Bernini, trans. Catherine Enggass (University Park: Pennsylvania State University Press, 1966), 74.

16 See Francesco Saverio Baldinucci, "Vita del Pittore e Architetto Andrea Pozzo," in Baldinucci, Vite di artisti dei secoli XVII-XVIII, ed. Anna Matteoli (Rome: De Luca, 1975), 314/c. 120v. Pozzo was baptized on December 1, 1642. ADT (Archivio Diocesano Trentino), Registro dei nati e dei battezzati della parrocchia della cattedrale di Trento, III, c. 36 . He was admitted to the Society as a temporal coadjutor at the Casa Professa of San Fedele in Milan on December 23, 1665 at the age of twenty-three. ARsi, Mediol. 55, Cat. Trien. $1672-1675$, f. $43^{\text {r }}$.

17 One such spectacle Pozzo likely witnessed was funeral of Bishop Carlo Emanuele Madruzzo (1599-1658) in December of 1658. Pompa funebre ne' funerali fatti nella Chiesa Cathedrale di Trento all'Eccellenza Reverendissima di Monsignor Carlo Emanuele Madruzzi, Vescovo, e Prencipe di Trento Co: di Chiallant \& c. Li 22 Decembre 1658 (Trent: Stampa Episcopale, 1659), 13-16. 
mostly likely some foundational studies in the sciences; the study of geometry and optics may have sparked an interest in perspective, leading ultimately to the pursuit of scenography and later quadratura fresco painting. ${ }^{18}$ Theatrical performance had been included in the activities of the Jesuit College at Trent from its founding. ${ }^{19}$ From the period of Pozzo's study at the college there are program$m i$ of at least three such performances held in early September of the academic year. ${ }^{20}$ We can imagine Pozzo taking part in these productions in some capacity, and he may well have contributed his artistic talents to the scenographies.

In the North of Italy, where Pozzo executed his first recorded scenographies as well as his first fresco projects, the Counter-Reform religious culture of Milan's famous reforming archbishops, Cardinals Carlo Borromeo (1538-84) and Federico Borromeo (1564-1631), continued to flourish in the frequent and elaborate rituals and festivals organized for feast days, canonizations and other religious occasions, as well as civic events. Jesuit theatre in Milan as well as other provinces included not only theatrical presentations in the colleges, but other types of spectacles which they designed and produced, including canonizations, religious devotions, triumphal entries, and state funerals. The festivities celebrating the canonizations of St. Ignatius of Loyola (1491-1556) and St. Francis Xavier $\left(1^{06}-52\right)$ in Milan in 1622 were recorded in a detailed printed account, complete with engravings, held in the Biblioteca Nazionale Braidense. ${ }^{21}$

18 Pascoli mentions the study of Latin and the humanities, although it is not known how far Pozzo progressed in the sciences. Lione Pascoli, "Di Andrea Pozzo," in Lione Pascoli, Vite de' pittori, scultori ed architetti viventi (Perugia: Electa, 1992), 691-706, here 691. The catalogue of the Jesuit Library of Trent between 1640 and 1660 includes volumes of Aristotle, Augustine, Aquinas, Caussin, Cicero, Plato, and manuscripts of Geometria and Cosmographia. Also included are works of Clavius, Galileo, and of course Athanasius Kircher. La Biblioteca del Collegio dei gesuiti di Trento: Pubblicazioni e manoscritti conservati nelle biblioteche trentine. Catalogo, vol. I. Edizioni sec. XV-XvıII, ed. Claudio Fedele, Italo Franceschini, et. al. (Abati-Pfyffer) (Trent: Provincia Autonoma di Trento, Soprintendenza per i beni librari e archivistici, 2007).

19 Amedeo Savoia, "Il teatro dei gesuiti a Trento fra XVII e XVIII secolo: Analisi di alcuni drammi manoscritti," in Mappe e Letture: Studi in onore di Ezio Raimondi, ed. Andrea Battistini (Bologna: Società il Mulino, 1994), 185-98. Savoia cites a production of Augustinus conversus ac resipiscens performed for Carlo Emanuele Madruzzo in 1626.

20 These included Ferrandus Gonzaga (1656), Conradus Secundus Imperator (1657) and Invidia triumphata (166o). Bruno Emmert, "Rappresentazioni fatte nel collegio dei gesuiti, nel liceo, ecc. in Trento: contributo bibliografico." Extracted from Atti della i.r. Accademia Roveretana degli Agiati, Series 4, vol. 1 (Rovereto: Editrice L'Accademia Rovereto, 1913).

21 Breve relatione delle solennissime feste, apparati et allegrezze fatte nella città di Milano per la Canonizatione de' Santi Ignatio Loyola Fondatore della Compagnia di Giesu, e Francesco Saverio suo compagno (Milan: Pandolfo Malatesta \& Gio. Battista Piccaglia, 1622). 
They began with a solemn evening procession, enthusiastically attended by the Milanese who decorated their windows and balconies with tapestries and hangings, and ending with a great display of lights and fireworks. ${ }^{22}$ The nineday celebration culminated with a parade following a long course from the College of Brera through the city, ending at the Jesuit church of San Fedele, which was preceded by a "theatre" of ephemeral architecture constructed for the occasion and decorated with sculptures, paintings and tapestries to celebrate the two saints, their virtues and their achievements. The parade floats featured fantastically costumed female allegorical figures-a device we find in Pozzo's fresco projects; in this case they represented the academic disciplines. ${ }^{23}$

Milan in the seventeenth century was under Spanish rule, and the Jesuits were frequently called upon to design rhetorical programs of text and images for major civic events honoring their Habsburg rulers, such as the triumphal entry of Maria Anna of Austria (1634-96) in 1649, among the most lavish in the city's history. Recorded in a monumental commemorative publication, the parade featured a series of triumphal arches decorated with sculpted figures, paintings, engravings and imprese hailing the Habsburg sovereign, and celebrating the family as Catholic rulers. ${ }^{24}$ Such grand processions of rulers and archbishops, and their elaborate arches and other scenographies, are defining events in the history of Milan in the early modern, much like the papal possessi (processions to celebrate newly crowned popes) in Rome. Citizens were directly involved in such occasions, those of higher rank participating in the procession, others observing from the decorated balconies and windows of their homes along the processional route. All engaged with reading the celebratory emblems and imprese adorning the arches, as well as the other decorations.

Theatrical performances also served an important role in celebrating the new sovereign, and the Jesuits of the Brera were sure to contribute their rhetorical skills to this endeavor as well. For the celebrations in honor of Maria Anna

22 Breve relatione, 13.

23 Gauvin Alexander Bailey has drawn an association between the kind of costume worn by the four women representing the four continents in Pozzo's ceiling in Sant'Ignazio and those worn by the actors and figures in festival processions throughout the Catholic world. Bailey, "Italian Renaissance and Baroque Painting Under the Jesuits and its Legacy Throughout Catholic Europe, 1556-1773," in The Jesuits and the Arts, 1540-1773, ed. John W. O'Malley, S. J. and Gauvin Alexander Bailey (Philadelphia: Saint Joseph's University Press, 2005), 123-98, here 195 .

24 La Pompa della Solenne Entrata fatta nella Città di Milano dalla Serenissima Maria Anna Austriaca (Milan: Gio. Battista e Giulio Cesare Malatesta, 1651). The copy cited belonged originally to the collection of the Collegio di Brera. 
of Austria they mounted a production of Theseus (or Il Teseo), a "tragedy with a happy ending, by the example of Euripides" on the stage of the Teatro Reale in the ducal palace, also described in the commemorative book. ${ }^{25}$ The piece was based on a story of Theseus, King of Athens, performed by the students of the Collegio di Brera in Latin, and featured elaborate and costly stage sets and effects. ${ }^{26}$ Jesuit theatre, clearly not confined to the colleges, found even greater and better financed opportunities in the courts for achieving persuasion through spectacle.

Pozzo would have been familiar with the engravings and accounts of these major events staged by the Jesuits in Milan from the earlier decades of the century, and was very likely involved in the elaborate staged productions at the Collegio di Brera as well as at the Milanese court. ${ }^{27}$ During his period teaching at the Collegio Romano, Pozzo would dedicate a substantial section of his treatise Perspectiva pictorum et architectorum (particularly the 1700 volume) to theatrical scenery. ${ }^{28}$ Pozzo's design for a theatre, as well as his scenographies, are indicative of many years of practice on the Jesuit stage, and certainly drew on his experiences in the theatres both in Milan and Venice. ${ }^{29}$

Pozzo's earliest recorded public works in the north of Italy were scenographies produced for religious occasions in Jesuit churches: the canonization festival for St. Francis Borgia (1510-72) in both Milan and Genoa in 1671; and a special festival of the Immacolata sponsored by the governor of Milan early the following year. ${ }^{30}$ In the brief accounts of both of the celebrations for

25 Argomento, allegoria et idea del Teseo, da rappresentarsi nel Regio Ducal Teatro da' scolari dell'Università di Brera della Compagnia di Giesù alla Potentissima Regina di Spagna N.S. Maria Anna d'Austria. (Milan: Filippo Ghisolfi, 1649).

26 Argomento, allegoria et idea del Teseo, 11-36. The scenographies for this production are described in La Pompa della Solenne Entrata, 48.

27 An example of a major production at the Brera staged during Pozzo's time in Milan is recounted in Gli orti esperii: Relazione dell'Apparato esposto dall'Università di Brera in occasione di ricevere l'Eminentissimo Principe Sig. Cardinale Vitaliano Visconti Borromeo (Milan: Ludovico Monza, 1668).

28 Andrea Pozzo, Perspectiva pictorum et architectorum, pars prima (Rome: Antonio de' Rossi, 1723; orig. 1693), figs. 72-77; and pars secunda (Rome: Antonio de' Rossi, 1723; orig. 1700), figs. $37-42$.

29 For Pozzo's time in Venice, see Baldinucci, "Vita del pittore," 319/125 Pozzo," 692; and Marina Carta et al., "Biografia," in Andrea Pozzo, ed. De Feo and Martinelli, 245-47, here 245 .

30 The canonization festivities for St. Francis Borgia in Genoa are recounted in Historia Domus Professae, transcr. Giulio Raffo, S.J., in Atti della Società ligure di storia patria, Nuova serie XXXVI (Genoa, 1996), Fasc. I, Anno 1672, 1 gennaio, 350. "I festeggiamenti in onore di S. Francesco Borgia." 
St. Francis Borgia, Pozzo's apparato (literally "apparatus," or display) is described within the wider context of the ritual. In Milan, the accounts describe the procession from the Duomo and the outdoor decorations throughout the city; in Genoa, the apparato is described within the context of the solemn ceremony, featuring the opulently decorated church and the rich sounds of the music. ${ }^{31}$ Both accounts mention the admiration and marvel with which the scenographies were received by their respective audiences.

The festival of the Immacolata, or immaculate conception, held at San Fedele on February 7,1672 marks the formal and official sanctioning of the doctrine in the Diocese of Milan. ${ }^{32}$ Pozzo's scenography for the event, not illustrated but described in detail in a printed pamphlet, was a complex architectural perspective vista which filled the entire opening of the presbytery and was populated by numerous figures. ${ }^{33}$ According to the account, the set "resembled a temple of ancient use, transformed into a great theatre, and with beautiful depth carried the eye to an ample perspective scene." ${ }^{34}$ The scenography comprised five architectural "scenes" arranged on a series of levels and opening one onto another, each framed by an arch. These scenes featured views into additional architectural spaces and structures, including a cupola and a semicircular "theatre." The whole arrangement climaxed in the fifth and final scene, an "arch of glory," framing the figure of the Virgin resembling the woman described in the Apocalypse: dazzling stars encircled her head, and

31 For the canonization of Francis Borgia in Milan, see Baldinucci, "Vita del pittore," 318-19/c.125 ${ }^{\mathrm{r}-\mathrm{v}}$; and Marco Cremosano, Memorie storiche milanesi di Marco Cremosano dall'anno 1642 al 1691: Per Giulio Porro Lambertenghi (Milan: Tipografia L. Bartoletti E. C., 1881), 34. For the festivities in Genoa, ASG [Archivio di Stato di Genova], Archivio Segreto, "Ceremoniarum," no. 477, 1659-71, 156 $6^{\text {r }}$ November 15, 1671, "Festa di S. Francesco Borgia."

32 Giovanni Battista Barella, Relatione della solennità, con quale l'Eccellentissimo Sig. Duca d'Ossuna Governatore di Milano, e Capitano Generale dell'Armi in Italia, fece Voto, e Giuramento di difendere la Gloriosissima Concezzione della Vergine Santissima Madre di Dio, e Nostra Signora, e della forma, con quale universalmente si celebrò in tutto lo Stato (Milan, c.1672), $2^{\mathrm{r}-\mathrm{v}}$. On the immaculate conception of Mary, see Aquinas, Summa theologiae, IIIa. 27.1-3; also T. A. Buckley, trans. Canons and Decrees of the Council of Trent (London: George Routledge and Co., 1851), Session v, 24.

33 Barella, Relatione dell solennità, $2^{\mathrm{v}}$. Anna Menichella provides a descriptive summary of the scenography: Menichella, "Il Pittore della casa di San Fedele," in Andrea Pozzo, ed. Vittorio De Feo and Valentino Martinelli (Milan: Electa, 1996), 8-23, here 14-17.

34 Translation mine: "Rassembrava un tempio d'uso antico, che andava à convertirsi in un gran teatro, e con bellissima fuga metteva termine all'occhio in un'ampia prospettiva." Barella, Relatione della solennità, $2^{\mathrm{v}}$. 
she stood on a moon encircled with clouds and angels. ${ }^{35}$ We can imagine the repeating motif of the triumphal arch, together with the series of ascending levels described, producing the sense of an ascending procession-not unlike the triumphal processions for monarchs and newly canonized saints described earlier — in which the faithful would have imagined engaging. All light sources were carefully concealed, including the lights illuminating the clouds; and the lighting functioned strategically with the highlights and shadows of the chiaroscuro painting to produce the greatest possible sense of depth. Furthermore, the church was darkened like a theatre, so that the apparato was the sole source of light; all light levels and light effects were perceived and experienced relative to the glorious scene to which the attention of the spectator was irresistibly directed.

This early representation of a heavenly scene rendered in architectural terms is a theme Pozzo would continuously develop throughout his career. Depicting heaven, and making it appear present and accessible within our worldly space, was a preoccupation of the age. ${ }^{36}$ Pozzo's particular approach was to give structure to the familiar scene of saints, prophets, angelic hosts, clouds and light by means of a believable architectural perspective system. He articulated the architecture for the scenography of the Immacolata as an extension of the interior architecture of the church of San Fedele, and this visual continuity reduced or eliminated the barrier between physical reality and the imagination, between the terrestrial and the celestial, between the quotidian life of the observer and the sacred scene represented. The project thus served as an early example of a recurring theme in Pozzo's work: "joining the fictive with the real": architecture and perspective connecting the spiritual vision to the built "reality." 37 The metaphysical implication of this phenomenon is that the observer, engaged in meditation on the object of devotion and the scene in which it is set, is both before the scene and fully immersed in it, achieving a kind of spiritual transport or mystical state, suspended somewhere

35 Barella, Relatione della solennità, $2^{\mathrm{v}}-3$. The image of the Virgin is derived from Revelation 12:1-2.

36 The tradition of frescoed domes depicting the heavenly hosts situated on ascending tiers of clouds extends back to Correggio's Assumption of the Virgin (1526-30) in the Cathedral of Parma; in Bernini's sculptural ensemble of the Cathedra Petri (1657-66) in St. Peter's and Gaulli's fresco The Triumph of the Name of Jesus (1676-79) in the Gesù in Rome, miraculous scenes of clouds, figures and light penetrate the church space, producing the visual effect of the celestial realm penetrating the terrestrial. See Warwick, Bernini: Art as Theatre, 45-54; and Weil, "The Devotion of the Forty Hours and Roman Baroque Illusions," Journal of the Warburg and Courtauld Institutes 37 (1974): 218-48, esp. 235-40.

"congiungendo il finto col vero," Pozzo, Perspectiva, I, fig. 30. 
between the physical reality of the church interior and the infinite space of the heavenly scene. The observer was thus called upon to "enter" the scene and participate in it. Such "entering" and "participation" are central themes in Ignatian spirituality as represented in Ignatius's Spiritual Exercises, in which highly descriptive narrative scenes encourage personal, performative involvement in the narrative of Christian salvation. ${ }^{38}$ All of the senses are called upon-sight, hearing, touch, smell, taste-in a kind of immersive meditation in which one is not merely observing the scene described, but entering it and becoming a participant. ${ }^{39}$ Pozzo's scenography thus became a means of visually enabling the kind of prayer and meditation the Jesuits promoted in their ministry.

The solemn service for the Immacolata began at seven in the morning on February $7,1672 .{ }^{40}$ The Lord Governor processed in with members of the Secret Council and representatives of the city's nobility, and Mass was celebrated by the bishop of the City of Vegevano, accompanied by several choirs. The Lord Governor then approached the altar and, kneeling, swore an oath to defend the doctrine, after which all members of the nobility and the state government followed suit. From this ceremony followed, hourly until two in the afternoon, the same rite of oath-taking by different administrative bodies, groups and religious orders of the city. The scene of devotion represented by the scenography was continually approached and reflected upon as each individual took the oath in the full solemnity of a ritual of both church and state.

Gesture held an important place both in the performance of such a ritual and in the scenography which accompanied it. In his treatise on gesture and prayer, De contemplationis gestu et actione, Federico Borromeo describes kneeling as a deliberate diminishment of ourselves and our powers, attributing the gesture to the "ancients" and speaking of the value of the pain that comes from this gesture of supplication. ${ }^{41}$ Within the ritual context of the Mass and of devotions such as that of the Immacolata, gestures become the performed choreography of religious theatre. In addition to the gestures enacted by

38 St. Ignatius of Loyola, The Spiritual Exercises of Saint Ignatius, trans. Anthony Mottola (New York: Doubleday, 1964). Many other editions available.

This method, after being established early on, is employed throughout the Exercises with varying emphasis on hearing, sight, etc. The most frequently cited is the fifth exercise of the First Week, the Meditation on Hell, in which the senses are called upon in a specific order: seeing the fires, hearing the wailing, smelling the smoke, tasting bitter things, touching the flames. St. Ignatius of Loyola, The Spiritual Exercises, "The Fifth Exercise."

40 For the account of the rite see Barella, Relatione della solennità, $3^{\mathrm{v}}-4^{\mathrm{v}}$.

41 Federico Borromeo, De contemplationis, gestu et actione, in вам [Biblioteca Ambrosiana Milano], f 5 inf. (Milan, c.1610-31), Book 5, chap. 22, "Degli ossequij delle ginocchia," $195^{-97}$. 
participants in the ritual of the Immacolata, gesture played an important role in Pozzo's scenography: the sibyls and prophets described, as well as the Virgin Mary herself, would all have been charged with dramatic movement and engaged in signifying gestures. The angels surrounding the Virgin are described as being engaged in "various guises," turning or playing instruments; above the scene two angels sounded trumpets announcing the glories of the immaculate conception, and drew back the great drapery which revealed the great tableau. ${ }^{42}$ Such gestures contributed to the performance of a visual narrative which celebrated the Virgin Mary's important place within Catholic belief as the means by which God entered the world.

Complementing the external performance of the rite, including the gestures of worship, moving through the church space, approaching the altar in procession and kneeling in obedience and reverence, religious theatre of this kind included an internal component: the silent ritual of prayer and reflection, in which all would have engaged over the long period of the devotion. The scenography appealed to the mind and the imagination, providing images which inspired this internal reflection. The scenography for the Immacolata and its role in the rite thus serve as an illustration of the idea of the "interior theatre" which Carla Bino has discussed in the examination of Federico Borromeo's I tre libri delle laudi divine (1632) and I sacri ragionamenti (1640), in which he sought to redefine and invigorate sacred theatre within the liturgical context. ${ }^{43}$ In this theatre, images-both those received through the senses and those produced in the mind-play a key role in meditation as well as in worship. Where the "interior theatre" of imagination and memory meets the exterior is in the gesture and the word of ceremonial worship. ${ }^{44}$ The religious scenography provides a physical environment for performed worship, as well as images and rhetorical devices which inspire the imagination and the memory. These, in turn, find external expression in the movement and gesture of ceremony. In the process of translation of action from interior to exterior performance which Bino describes, the "exterior signals" function like animated images that ignite the soul and give expression to mental images. ${ }^{45}$ The interior performance thus mirrors the exterior performance, the two engaging in a relationship of reciprocal

\footnotetext{
42 Barella, Relatione della solennità, $3^{\mathrm{r}}$.

43 Bino, "Lo spiritual teatro e la sacra scena: Una prima indagine negli scritti di Federico Borromeo," Studia borromaica 16 (2002): 263-82.

44 Bino, "Lo spiritual teatro," 273. Bino cites Borromeo, De contemplationis, gestu, et actione, $1-4$.

45 Bino, "Lo spiritual teatro," 273.
} 
exchange.$^{46}$ Pozzo's scenography for the Immacolata became a theatrical space for two kinds of performance: the "exterior theatre" of the ritual held in the church for the religious event itself, and the "interior theatre" of the individual performance, comprising private devotion and meditation.

Pozzo's first great successes after he arrived in Rome in the early 168 os were religious scenographies for the Quarant'ore, or Devotion of the Forty Hours, and we are fortunate to have several of these projects recorded in detail in his treatise. The Quarantore is a type religious theatre for which the Jesuits were well-known, and for which Pozzo was called upon to produce elaborate scenographies, first in Milan and later in Rome. ${ }^{47}$ Beginning in the mid-sixteenth century, the Jesuits in Italy made a practice of holding the Quarant'ore in the last three days of Carnival, in order to dissuade people from the carnal pleasures of the season and to attract them to the light of salvation in preparation for Lent. The scenographies produced for the Quarant'ore in Rome, held in a series of churches in succession, became increasingly elaborate as the seventeenth century wore on. At the Gesù, where they were produced by the Congregation of Nobles in collaboration with the Jesuits, the prestigious annual commission featured the work of prominent Roman artists including Niccolò Menghini (1610-65) and Carlo Rainaldi (1611-91).48

The Quarant'ore in the early modern period was a rite involving movement, sound, smell and the full range of the senses in addition to sight. The devotion began and ended with a solemn sung Mass, followed by a procession, which would begin in the church and proceed outdoors, depending on the weather. ${ }^{49}$

46 Bino, "Lo spiritual teatro," 269.

47 For the Quarant'ore in Italy and a more expanded study of Pozzo's contributions to the tradition in Rome, see Andrew Horn, "Teatri sacri: Andrea Pozzo and the Quarant'ore at the Gesù," in The Holy Name: Art of the Gesù. Bernini and His Age, Early Modern Catholicism and the Visual Arts, vol. 17, ed. Linda Wolk-Simon (Philadelphia: Saint Joseph's University Press, 2018), 351-82.

48 For the history of the rite at the Gesù, including the scenographies of Menghini (1640) and Rainaldi (1650), see Horn, "Teatri sacri," 352-59. The Congregation of Nobles, known more formally as the Marian Congregation of the Nobles of the Gesù, was founded in 1593 and granted a chapel for worship in the Casa Professa of the Gesù, where they still hold weekly services today. Giuseppe Castellani, S.J., La Congregazione dei Nobili presso la Chiesa del Gesù in Roma (Rome, 1954) 39-50, 60.

49 For the form of the Quarant'ore as practiced beginning in the late sixteenth century, see Carlo Borromeo, Instructiones pro Oratione quadraginta horarum/Avvertenze per l'oratione delle quaranta hore, June 15, 1577. In Acta Ecclesiae Mediolanensis, vol. I, Instructiones varie, 81-682 (Lyon: Anisson and Posuel, 1683). Seventeenth-century popes including Urban VIII (1625), Alexander VII (1655), and Innocent XI (1681) published their own Istruzioni for Roman churches, essentially repeating Borromeo's instructions, with variations primarily in the decorations. 


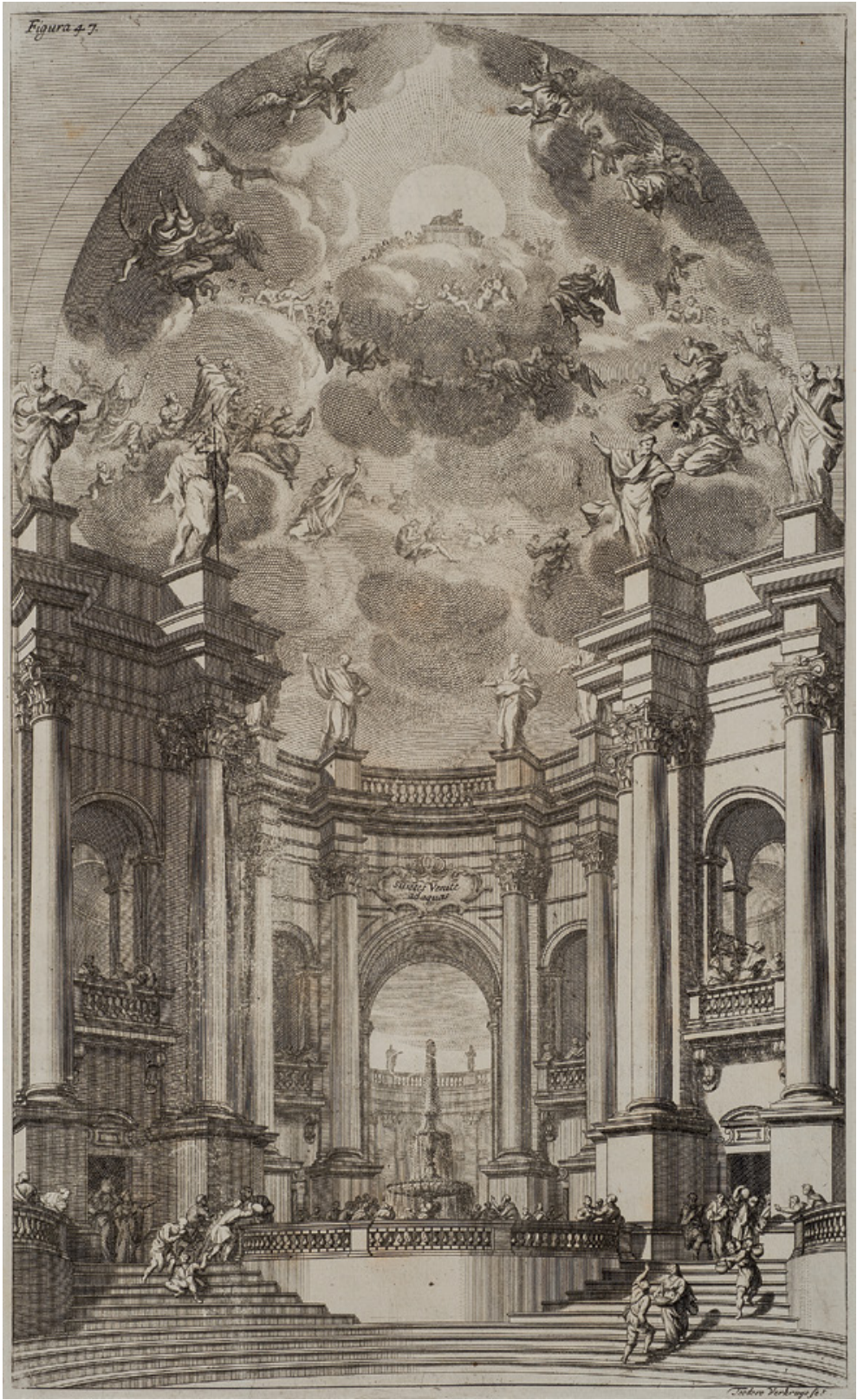

FIGURE 3.1 Andrea Pozzo, Sitientes venite ad aquas: scenography for the Quarant'ore in the Gesù, 1695, engraving. Perspectiva pictorum et architectorum, II, Fig. 47. Private Collection, New York PHOTO BY PAUL MUTINO 
Apart from the Masses, litanies and sermons, the devotion was largely an opportunity for silent prayer and reflection. As in the festival of the Immacolata, the scenography served a function that was not merely decorative: throughout the long periods of reflection, the interior theatre of the worshipper utilized images to activate memories of scriptural narratives associated with the mystery of Christ's sacrifice and the Eucharist, and to encourage guided meditations, as he or she was called to actively participate in the dramatic narrative of salvation. The physical participation in the actions of the ritual, particularly those of the Mass, provided the opportunity to outwardly perform this narrative in community. Thus to an even greater degree than we have seen in the ritual for the Immacolata, the "interior theatre" of the vigil of the Quarant'ore functioned simultaneously with the "exterior theatre" of the physical performance of the ritual.

Devotional treatises of the time give us a sense of how the faithful were provided a structure, a "script" for the performance and particularly for the interior theatre of the rite, and guided in understanding its multiple meanings. ${ }^{50}$ In 1605 , the Jesuit Luca Pinelli of Naples (1542-1607) produced a series of forty spiritual exercises for the devotion, Quaranta essercitii spirituali per l'oratione delle Quaranta hore (Forty spiritual exercises for the Devotion of the Forty Hours) which provides guidelines for the practical aspects of the rite as well as extensive commentary on its symbolism..$^{51}$ Pinelli's treatise closely resembles the Spiritual Exercises of Ignatius in its structure, method, and emphasis on the senses. Each hour of the devotion begins with a point of meditation, followed by a colloquio, or conversation with oneself or God related to a theme; an oration or prayer; and finally the story of a miracle associated with the Blessed Sacrament. In the eighth exercise, which is particularly relevant to church architecture and decoration of the period, Pinelli emphasizes the senses and recalling the rich sights and sounds of ceremony. Pinelli asks the exercitant to contemplate the churches throughout the world, magnificently designed and built to serve the divine worship of the Blessed Sacrament on the altar; the tabernacles, altar decorations, and rich sacerdotal vestments; the solemn processions, the multitude of lights, and the music. ${ }^{52}$ Pinelli's treatise, taken as a whole, serves as a guide and a structure for the meditative component of the Quarant'ore- the "interior theatre" which occupies the majority of the

50 A literature of surviving printed texts includes instructional treatises, spiritual exercises, printed sermons and music composed for the rite, beginning at least as early as the 1570s. These were produced by Jesuit houses as well as other religious orders and dioceses throughout mainland Italy and Sicily. Luca Pinelli di Melfi della Compagnia di Giesù (Naples: Felice Stigliola, 1605). 
forty-hour period, and the role of images within this theatre. Where cultural context is concerned, it provides a framework for understanding the enormous importance which the Quarant'ore assumes in the religious life of seventeenthcentury Italy and the key visual themes that come to play in the scenographies produced for the rite.

Pozzo's apparato for the Quarant'ore at the Gesù of 1695, represented in the second volume of his treatise, is among the most innovative of all the surviving designs of his scenographic career (Figure 3.1). ${ }^{53}$ This work is typically referred to as Sitientes Venite ad Aquas, after the inscription in the cartouche over the central arch. The words come from Isaiah 55:1: "Come, everyone who thirsts, come to the waters." Rather than portraying a specific narrative from scripture in this apparato, Pozzo presents the fountain of salvation as the symbol of Christ; in this way the scene may be considered to represent all of the scriptural passages related to water and baptism. The theme of Christ as the source of salvation is further reinforced by the image of the Mystic Lamb in the apse above: Christ is the sacrifice that saves all mankind, for all time. ${ }^{54}$ The figures in the scene below are anonymous, and therefore can be said to represent all of humanity: the scene is one of universal salvation and wonder. The grandiose architectural scene of Pozzo invites all to come forward and partake of the saving waters. Thus the Eucharist, and its saving power, are demonstrated as universal, timeless, and eternal.

The dominant motion of the scene is circular: the Mystic Lamb, and the Blessed Sacrament (one doubling as the other) are the cosmic centre around which the heavenly hosts and all things move and "have their being." ${ }^{55}$ This theme is reflected in the architecture of repeated curving and circular and arrangements: the major arch echoed by both the minor arches with balusters and the arches in the remote distance, the curve-and counter-curve of the platform and the steps, the round structure crowned by a "theatre of saints" on the top-all echo the spiralling motion and perspective of the scene of the Mystic Lamb in the apse above.

The direct involvement of the senses and the appeal to the imagination which the prayers and exercises of the Quarant'ore devotion encouraged were complemented by the apparent physical presence of a miraculous scene. Such

53 This project is illustrated and described in Pozzo, Perspectiva, II, figures 45 to 47 . Its date of 1695 is given in Pozzo's text accompanying Figure 45.

54 The scene represents the Lamb from the Apocalypse: Revelation 5-9.

55 Acts 17:28 (quoting Paul): "In him we live and move and have our being." See also St. Thomas Aquinas, Summa theologiae, 1a.2.3; see especially Aquinas's proofs based on "change" and "the nature causation." 
an apparato would have served as a metaphor of spiritual exaltation and as the source of powerful visual cues for the meditations and rites of the devotion. In his description of this apparato, Pozzo proudly relates the anecdote of spectators so convinced of the illusion that they wanted to climb the steps: "I remember having seen persons who wanted to climb these stairs, without realizing the error, to the point of touching them with their hands." ${ }^{56}$ Thus with Pozzo, the religious scenography succeeds in producing in the observer the visceral desire to "enter," and to make physical contact with the scene of glory, as the faithful seek to ascend to the place of the miracle and the source of salvation. The interior theatre of the imagination meets the exterior theatre of the ritual as the spectator momentarily feels capable of physically entering the scene of devotion.

As works of applied perspective, Pozzo approached his illusionistic painting projects in much the same way as his ephemeral scenographies. Indeed, in spite of the obvious difference in materials and execution, these projects are in effect large scenographies executed across multiple planes and varying surfaces. Where they most radically differ in their application of perspective is in the effects they produce for the observer moving through the space in stages. The principal question in Pozzo's studying illusionistic works is the motive behind these effects-why he places viewing positions and vanishing points where he does - and the answer lies in their ritual contexts. Pozzo's innovation is manifest in the role of the moving observer; and this role of the observer should be considered not only in terms of visual experience, but in terms of performative and even ritualised movement within the space. ${ }^{57}$ Both independently and within the wider architectural context in which they are situated, the fresco cycles of Pozzo function as teatri sacri, or sacred theatres; and I qualify this reading based on the experience of the moving observer, his or her individual engagement with the images, and his or her engagement in the rituals for which the architectural spaces are designed and decorated.

Pozzo's most significant surviving fresco project in Northern Italy is his work in the church of San Francesco Saverio at Mondovì (1676-78), a small town in Piedmont (Figure 3.2). The church, built and decorated to celebrate the society's missionary saint Francis Xavier, was designed by Giovenale Boetto

$5^{6}$ Translation mine. The full passage: "Tanto è vero che i disegni di opere grandi fatti con buona regola di architettura, pittura, e prospettiva gabano l'occhio: ed io mi ricordo aver veduto persone, che volean salir queste scale, senza avvedersi dell'errore, finche non le toccaron con le mani." Pozzo, Perspectiva, II, fig. 47.

57 For the visual experience of moving through Pozzo's perspective systems, see especially Burda-Stengel, Andrea Pozzo and Video Art. 
(1604-78), architect, scenographer, and painter active primarily in Piedmont. ${ }^{58}$ With its system of arches, supported alternately by fully disengaged columns, half columns and pilasters, the interior architecture of the church produces a visual effect remarkably analogous to the series of lateral wings and portals comprising a baroque stage set, not unlike those of Giacomo Torelli (1608-78) in Venice.$^{59}$ Like the religious scenographies of the period, including those of Pozzo considered earlier, the church provides an ideal study of architecture, figures and decoration functioning together as religious theatre.

Boetto's subdivision of the ceiling of the church with the arches meant that the large central vault of the nave and the apse over the altar provided the only two opportunities for expansive fresco scenes. In spite of such apparent limitations, Pozzo's fresco program goes beyond the function of decoration or pictorial narrative and iconography by illusionistically extending and opening the structure beyond its constructed confines. Here he employed a system of perspective that tested the technical limits of the art: a complex combination of images projected onto curved, vaulted and otherwise irregular surfaces, with angled viewing positions strategically placed to coordinate with the position of the observer moving through the space. These viewing positions correspond with the individual features comprising the overall scheme: the recessed bands of the vault between the arches, the cupola, and the apse.

Within this extraordinary perspective system, Pozzo depicted scenes and images forming an iconographic program associated with a specific event: the canonization of Saint Francis Xavier in 1622 by Pope Gregory XV (1554-1623), an event further proclaimed in Urban viII's bull of canonization the following year. ${ }^{60}$ The complex program of visual rhetoric in praise of the missionary

$5^{8}$ Nino Carboneri and Andreina Griseri, Giovenale Boetto (Fossano: Cassa di Risparmio di Fossano, 1966), 9. The building history of the church is documented in the State Archives of Turin: AST [Archivio di Stato di Torino], I, Conventi Soppressi, Mondovì.

59 Several authors have drawn this comparison; most recently Richard Bösel and Lydia Salviucci Insolera, "Teatrizzare la stessa architettura'. Lo spazio sacro come palcoscenico a quinte," in Mirabili disinganni, ed. Richard Bösel and Lydia Salviucci Insolera (Rome: Artemide, 2010), 249-51; and Silvia Carandini, "Dalle quinte del teatro alla macchina d'altare. Andrea Pozzo e le pratiche sceniche del suo tempo," in Andrea Pozzo a Mondovi, ed. Heinrich W. Pfeiffer, S.J. (Milan: Jaca Book, 2010), 156-79, here 169.

6o Urban VIII issued the bull in August 1623, to affirm Francis Xavier's canonization by Gregory XV on March 12 of 1622 . Pope Urban VIII, Canonizatio S. Francisci Xavierij è Societate Iesu, Indiarum Apostoli, eiusque in Sanctorum Confessorum numerum adscriptio, cum institutione eius festivitas die 2. mensis Decembris, in Magnum Bullarium Romanum, Pontificum Urbani virI \& Innocentiix. Constitutiones Complectens: Editio Novissima, 4 vols. (Lyon: Philippe Borde, Laurente Arnaud, \& Claude Rigaud, 1655), 4:15-20. See Pfeiffer, "Liconografia e il messaggio del San Francesco Saverio," in Andrea Pozzo a Mondovi, 6o129, here 61 . 


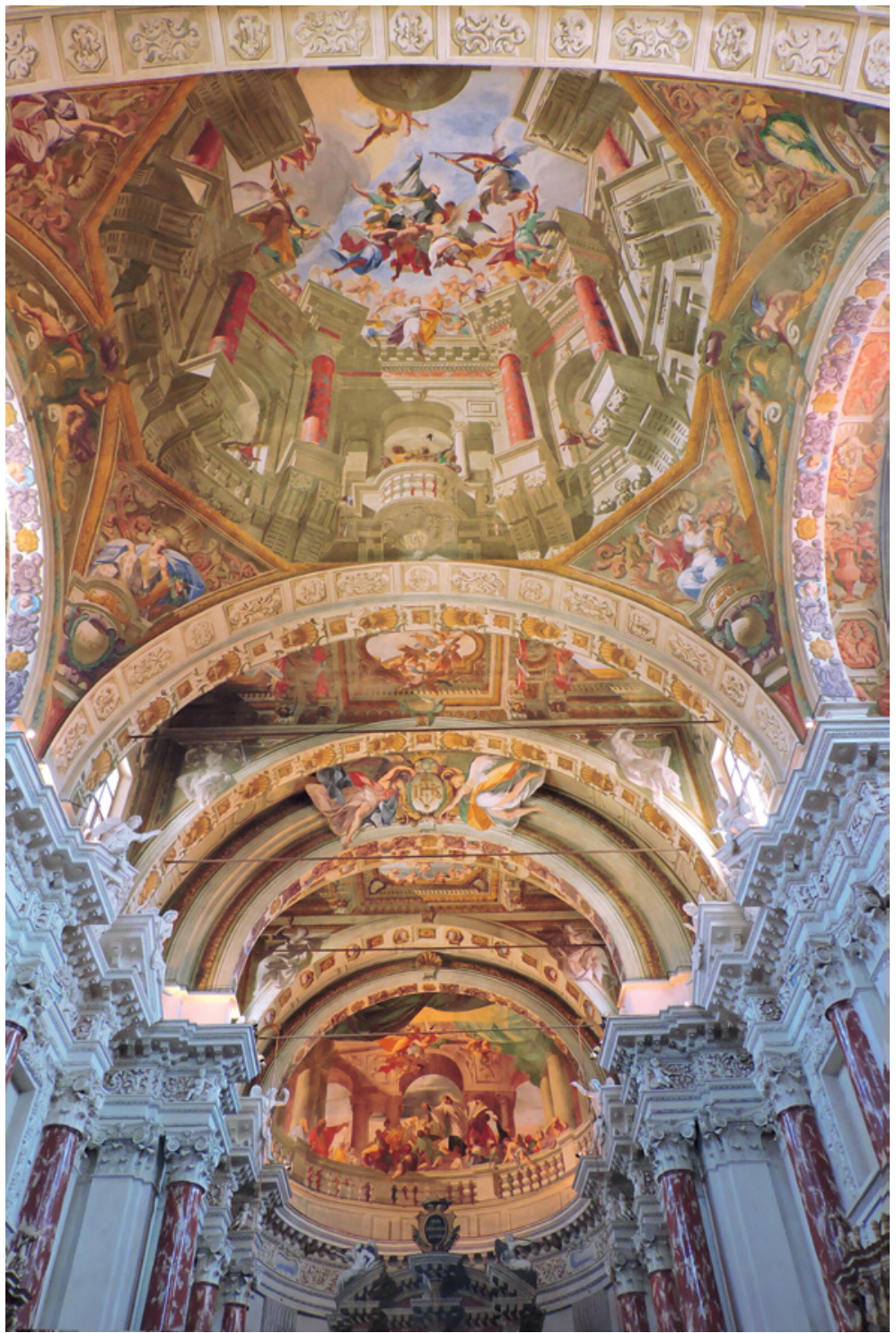

FIGURE 3.2 Interior, San Francesco Saverio, Mondovì. Architecture by Giovenale Boetto, 1665-75. Frescoes and decorative painting by Andrea Pozzo, 1676-78 PHOTO BY THE AUTHOR

saint and his virtues combines with the constructed architecture of the church to form a sacred theatre for performed ritual and devotion. In its architectural and iconographic progression, the interior of the church might be said to correspond to the elaborate religious processions of the period, like that produced for Maria Anna of Austria mentioned earlier, or the entries of new 
archbishops; all were choreographed using a series of triumphal arches decorated with figures, painted images, inscriptions, and imprese. ${ }^{61}$ In addition to elaborate processions, canonization festivals of the time, like those celebrating Saints Ignatius and Francis Xavier and St. Francisco de Borja in 1622, centered on the local church associated with their order. The church was always richly decorated for the occasion with a variety of devices such as framed painted scenes of the saint, his or her deeds and virtues, inscribed tablets and medallions, festoons and bouquets of flowers, ribbons and hanging drapery swags. ${ }^{62}$ The interior of San Francesco Saverio in Mondovì was similarly transformed, through Pozzo's painting work, into a permanent scenography for a canonization festival re-enacted in perpetuity.

The major scenes of the saint, together with a system of symbols depicting his graces and virtues, are portrayed in the church in a sequence in coordination with spatial progressions established by the architecture. In this way, painted imagery, perspectival illusionism and architecture-both fictive and real-are tied together in a complete teatro sacro. While the church at Mondovì and its decorative programs are not necessarily designed to follow, complement or specifically reference the Spiritual Exercises, we can trace a sequential engagement of the senses which establishes a spiritual narrative and produces a sense of ritual procession. Upon entering, the observer is presented with the dense and complex visual effects of the interior. As the observer proceeds through the church, the entire ensemble of architecture and painting, which features the major scenes concerning the saint and the allegories and emblems of his virtues, seeks to engage him or her in a process of recognition, contemplation, and wonder. This process in turn may be said to engage the three faculties of the soul that are core to the Spiritual Exercises: memory, understanding, and will. ${ }^{63}$

Pozzo's frescoes feature scenes and motifs which not only engage the sense of sight, but suggest a rich experience of sounds and even smells. In the narrow band over the entrance, a small octagonal opening reveals a glimpse of heaven

61 Milanese examples include the procession for Maria Anna of Austria described earlier, and the entry of Archbishop Cesare Monti in 1635: Apparati e solennità dell'ingresso in Milano dell'Eminentissimo e Reverentissimo Signore Cardinale, Arcivescovo Cesare Monti: Alli 29 d'Aprile dell'Anno 1635 (Milan: Filippo Ghisolfi, 1635).

62 Santa Maria dei Servi in Milan was thus decorated in 1671 for the canonization of Filippo Benizi. This event is described in Cremosano (Memorie storiche, 34, entry for August 23, 1671). The interior of Santa Maria dei Servi is represented in a rare print held in Milan's Civica Raccolta delle stampe Achille Bertarelli.

63 The three faculties are explained and given examples in Ignatius's Spiritual Exercises. 
and putti engaged with flowers and fruits, symbols of the saint's virtues and his good works, respectively; as well as pearls, symbols of divine favor. ${ }^{64}$ These are flanked by openings to the left and right, through which we see an angel playing a lute, and another a violin. On the left and right side of each arch, adjacent to the windows, is a series of female figures painted as grisailles in chiaroscuro, resembling sculpted reliefs. These represent twelve virtues, including the theological virtues and heavenly virtues, intended to help the faithful "to imitate the missionary saint." 65 Pozzo's system of figures, narrative scenes and motifs, experienced as the observer proceeds through the church, appeals to his or her memory of the miracles, events and achievements of the saint; understanding of his role as a missionary to convert souls, the qualities required for such a vocation, and his ultimate sacrifice; and the will to follow his example.

The cycle climaxes in Pozzo's most dramatic pictorial and illusionistic moment: an octagonal cupola, entirely produced in painted perspective, open to the heavens and populated by highly animated groups of figures. The four pendentives are decorated with female personifications of the four known continents-Africa, Asia, America, and Europe-which represent the order's mandate of global evangelization. This theme, possibly inspired by the fancifully dressed allegorical figures featured in parade floats such as those described in the canonization festival for Ignatius and Francis Xavier earlier, would appear again in Pozzo's famous ceiling in Sant'Ignazio in Rome. ${ }^{66}$

Although it visually corresponds to the constructed architecture of the church, the cupola is an early demonstration of Pozzo's "theatricalized" architecture: the structure, in its complexity, movement and many openings and balconies, seems in large measure designed to accommodate groupings of figures, their activities and their interaction, and to reveal the miraculous scene above. An orchestra of musicians on balconies performs a "concert" completed by angel musicians. ${ }^{67}$ In the heavenly paradise we see Francis Xavier's apotheosis: the saint is carried up to heaven by a host of angels in a scene analogous to the "happy ending" of a Christian tragedy of the

64 Pfeiffer, "Liconografia e il messaggio," 61.

65 Pfeiffer, "Liconografia e il messaggio," $82-91$. The seven virtues Pfeiffer refers to include the theological virtues Faith, Hope, and Charity (1 Cor. 13:1-13), plus the classical cardinal virtues of Prudence, Justice, Temperance, and Courage.

66 Bailey has drawn an association between the kind of costume worn by the four women representing the four continents in Pozzo's ceiling in Sant'Ignazio and those worn by the actors and figures in festival processions throughout the Catholic world ("Italian Renaissance and Baroque Painting," 195).

67 Pfeiffer, "L'iconografia e il messaggio," 68-82. 
period, a dramatic genre for which the Jesuits were known. ${ }^{68}$ Such works frequently featured an apotheosis in which the saint was "transformed into an instrument of glory": the apotheosis was the catharsis which came, and which was earned, at the end of a saintly life. ${ }^{69}$ Such works, like their classical counterparts, were intended to spiritually and morally edify their audience, providing them with a model of perfection in the figure of the saint. ${ }^{70}$ The "happy ending" that distinguished the Christian tragedy from the classical tragedy derived from the idea that death itself was not an end, but the gateway to salvation and eternal life. ${ }^{71}$

In the apse, we come to the sole narrative scene in this fresco cycle drawn directly from accounts of the saint's life: the great event of the baptism of Queen Neachile in India, who was deposed and ultimately executed for her conversion, an event recorded by Daniello Bartoli $(1608-85) .^{72}$ The central scene is that of St. Francis baptizing the queen, accompanied by an assistant struggling with a great book of scripture. The figure of the queen is presumed to represent the Duchess Marie Jeanne Baptiste (1644-1724), recently made Regent of Savoy. ${ }^{73}$ The new Savoy queen, performing the role of Queen Neachile, bends her head in submission to baptism and to Christ, showing by example her obedience, as a sovereign, to the one true Church. In the manner of a Christian martyr, Neachile lost her reign and ultimately her life in exchange for her conversion and defence of the faith. The local monarch thus doubles as the legendary martyr in a religious historical drama performed in the apse.

The fresco in the apse is an early demonstration of the grand theatrical tableau of performing figures and architecture, reminiscent of Veronese, which

68 See Zanlonghi, "La tragedia fra ludus e festa: Rassegna dei nodi problematici delle teoriche secentesche sulla tragedia in Italia," Forme della scena barocca, ed. Annamaria Cascetta, Comunicazioni sociali 2-3, anno XI (April-September 1993): 157-240; also Cascetta, "La 'spiritual tragedia' a l'azione devota': Gli ambienti e le forme," in La scena della gloria, ed. Cascetta and Roberta Carpani (Milan: Vita e Pensiero, 1995), 115-218.

69 Zanlonghi, "La tragedia fra ludus e festa," 205-7 and 210-11.

70 An example Christian tragedy featuring Francis Xavier intervening to perform miracles on behalf of the converted: Alessandro Donati Pirimalus Celiani Princeps (or) Pirimalo, tragedia da recitarsi nel Coll. Rom. da gli academici Partenii nelle feste della canonizatione di S. Francesco Saverio spiegata in breve argomento d'atti e scene da Gino Angelo Capponi (Rome: Zanetti, 1623).

71 Zanlonghi, "La tragedia fra ludus e festa," 207.

72 Daniello Bartoli, Dell'Istoria della Compagnia di Gesù: L'Asia, I (Milan: Dozio, 1831; orig. 1653), 166.

73 Pfeiffer, “Liconografia e il messaggio," 109. 
characterizes much of Pozzo's work. ${ }^{74}$ The device of the great drapery overhead, pulled back to reveal the scene, together with another suspended over the architectural structure, bring this apse painting into close association with religious scenographies, including that produced by Pozzo for the Immacola$t a$ in Milan discussed earlier. The entire scene is set behind a balustrade, and backed with a Palladian arcade, the central opening of which serves as a final triumphal arch, with an infinite expanse of blue sky beyond. In addition to serving as a performed narrative drawn from the saint's life for the faithful to contemplate, this painted scene in the apse at Mondovì has the effect of visually opening the space to a limitless horizontal and vertical expanse beyond the framing arch. The curved wall of the apse virtually disappears.

The high altar at Mondovì is the church's most curious and truly scenographic element (Figure 3.3). It is Pozzo's only surviving ephemeral macchina, a rare surviving example of theatrical scenery from the seventeenth century. The structure is rendered using theatrical techniques of the day which Pozzo illustrates in the numerous scenographic projects in his treatise: a series of three theatrical flats, each shaped to the profile of the architecture and painted in perspective, produces, with the intervening space, the convincing appearance of a fully dimensional architectural structure. An image of Francis Xavier is painted on a metal panel and suspended in the midst of the system, and can be raised with the still extant apparatus of a mechanical winch, hidden behind the scaffold that supports the structure. This effect, intended to be seen by candlelight, is a representation of the miraculous levitation of the saint, described in Urban viII's bull of canonization, in which he was observed to enter a trance, his eyes fixed toward the heavens, overcome with the "fire of divine love. ${ }^{75}$

The ritual procession through the church as one observes the symbols and scenes of the saint represented in the frescoes, together with the effects of

74 Later examples include Pozzo's apse fresco in Sant'Ignazio, St. Ignatius as miracle-maker (1685-88) and his his Quarant'ore scenographies in the Gesù, particularly Le Nozze di Cana of 1685. Pozzo, Perspectiva, I, fig. 71. Veronese's Wedding Feast at Cana (1562-63), with its great variety of figures, gestures and costume, as well as the balustrade and the monumental columns framing the scene, is representative of an approach to the grand painted narrative to which Pozzo's fresco scene at Mondovì, as well as his later works in Rome, correspond.

75 "fieretque aliquando talis super eum mentis excessus; ut oculis in caelum defixis, divina vi a terra elevaretur; vultu adeo inflammatus, ut angelicam prorsus claritatem repraesentaret, nec divini amoris perferre valens incendium, sapeius exclamaret: Satis est Domini, satis est." Pope Urban viII, Canonizatio S. Francisci Xavierij è Societate Iesu. See Pfeiffer, "L'iconografia e il messaggio," 109. 


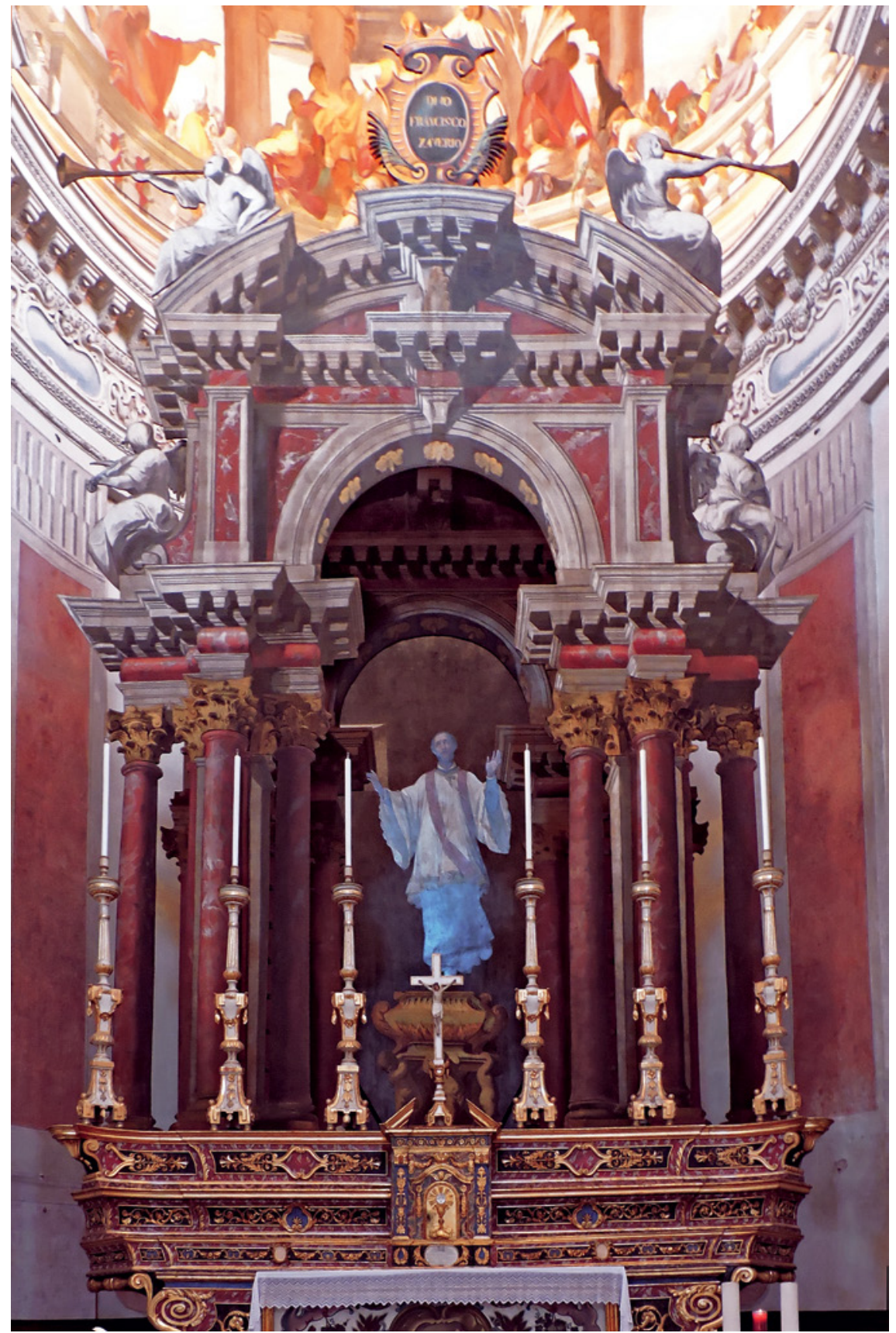

FIGURE 3.3 Andrea Pozzo, high altar, San Francesco Saverio, Mondovì, 1678 PHOTO BY THE AUTHOR 
the perspectival illusions, serves as a faith journey for both the individual and groups of faithful. Processions are a regular feature of Masses and religious devotions including the Quarant'ore, and the broad nave area typical of Jesuit churches of this period is designed to gather the community in prayer in a space which maximizes the communicative potential of rhetoric on both a visual and an auditory level. ${ }^{76}$ It is a space which encourages communal worship, and visually and acoustically serves as an ideal setting for preaching. In addition to the regular schedule of masses and prayers, the celebration of the feast day of St. Francis Xavier, which assumed particular importance in this church and its liturgical year, is demonstrated in the apparatus of the levitating saint featured in the ephemeral high altar. ${ }^{77}$ The church is thus a place of both an internal and external performance, of individual and communal ritual performed both separately and simultaneously. In the context of the church at Mondovi, thought and action engage alternately in the movement through the space and the reception of the images and their meanings. ${ }^{78}$ The apparato of the altar, like Pozzo's previous apparati, becomes a means of directing attention toward the object of devotion, but also a means of participating in the spiritual drama of the Eucharist. Francis Xavier performs his baptism, and

$7^{6}$ The preference of the Jesuits for single-nave church plans (although not exclusive) is evidenced by both realized church buildings and numerous designs from the late sixteenth century onward. See Bösel, "La ratio aedificiorum di un'istituzione globale tra autorità centrale e infinità del territorio," in La arquitectura jesuítica: Actas del Simposio Internacional celebrado en Zaragoza, ed. María Isabel Álvaro Zamora, et al. (Saragossa: Institución "Fernando el Católico," 2012), 39-69. See also Vallery-Radot, Le recueil de plans d'édifices de la compagnie de Jésus, Biblioteca Instituti Historici S.I. 15 (Rome: Institutum Historicum Societatis Iesu, 1960). The Jesuits' insistence on this plan for purposes of preaching and liturgy is discussed by Ackerman in "The Gesù in Light of Contemporary Church Design," in Baroque Art: The Jesuit Contribution, ed. Rudolf Wittkower and Irma B. Jaffe (New York: Fordham University Press, 1972), 15-28. Although this type of plan in Jesuit architecture is typically regarded as beginning with the Gesù and the Roman tradition, Ackerman suggests it had precedent in Northern Italy, independent of ideas of the Counter-Reformation concerning liturgy.

77 The feast day of St. Francis Xavier is December 3, and in the records relating to the church and the college at Mondovì, we find in 1683 a plenary indulgence offered to those participating in the church services. AST, I, Conventi soppressi, Mondovi, fol. 234, 9 Consuetudini del Collegio. In 1729, receipts indicate musicians and a choir paid for both the Mass and the vespers. AST, I, Conventi soppressi, Mondovi, fol. 230, Festa di S. Francesco Xaverio, 1729.

${ }_{78}$ In her overview of the theoretical discourse on ritual, Catherine Bell summarizes the dichotomies presented between thought and action, individual and group, ritual and belief, "actor" and "detached observer." Bell, Ritual Theory, Ritual Practice (Oxford: Oxford University Press, 1992), 19-29. 


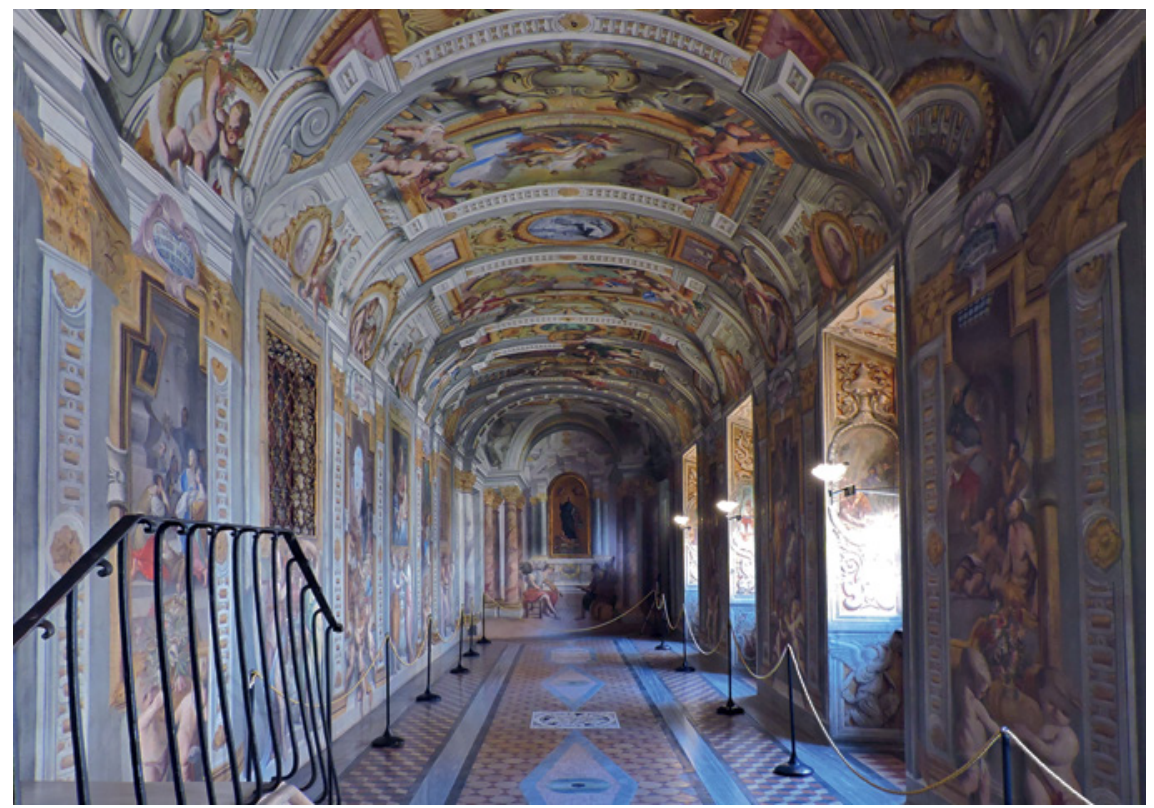

FIgure 3.4 Andrea Pozzo, fresco cycle, Corridor of Saint Ignatius, c.1682-86. View from entrance. Casa Professa del Gesù, Rome

PHOTO BY THE AUTHOR

the faithful approach the saint to participate in this baptism and assist him in his miraculous levitation and ascent to heaven, represented in the cupola above. ${ }^{79}$ Ritual, movement, architecture, image and scenography make San Francesco Saverio at Mondovì among the most integrated of the Jesuits' teatri sacri.

I will conclude with another relatively unknown fresco cycle of Pozzo, but one which to me counts among the most extraordinary Jesuit "theatres" of the seventeenth century. The Casa Professa del Gesù in Rome, the Jesuit house attached to the mother church of the Gesù, is the place where St. Ignatius spent the last ten years of his life, and where he died on July $31,1556 .^{80}$ The veneration with which the Society regarded the rooms of the saint in the house is clearly evidenced by the decision of Superior General Claudio Acquaviva (1543-1615) to preserve the rooms, a full decade before Ignatius' beatification and more

79 Pfeiffer describes the spectator assisting in the saint's levitation in "Liconografia e il messagio," 109.

80 Thomas Lucas, S.J. "La Galleria del Pozzo nella Casa Professa a Roma: Una teologia riscoperta," in Andrea Pozzo, ed. Alberta Battisti (Milan: Luni Editrice, 1996), 141-43, here 141. 
than twenty years before his canonization. He chose to literally ensconce them within the structure of the new Casa Professa, which was begun in $1599 .{ }^{81}$ By the middle of the seventeenth century, the amply-lit corridor which runs between the garden courtyard of the building and the rooms of the saint terminated in an altar, and had become a place of extensive visitation and pilgrimage. A decorative program for the corridor had been begun by Jacques Courtois in 1661 , but was not completed before his sudden death in $1676 .^{82}$

Under Superior General Giovanni Paolo Oliva (1600-81) the corridor and its decoration became a renewed priority, and it has been inferred from his enthusiastic correspondence with Pozzo, as well as the account by Lione Pascoli, that he was planning to make the project of the corridor Pozzo's first Roman commission. ${ }^{83}$ In spite of Oliva's death shortly before Pozzo's arrival in Rome, the project was resumed under Superior General Charles de Noyelles (1615-86), who called upon Pozzo to produce a fresco cycle celebrating Ignatius of Loyola, and to confer a sense of beauty and spaciousness upon what was a rather unremarkable architectural space. Noyelles was convinced that with Pozzo's project, the corridor would undergo a transformation, becoming "no longer simply a corridor, but a beautiful and magnificent portico for the chapels, that would render them more noble and venerable," making the site, "one of the most beautiful sanctuaries of Rome, worthy of being admired and revered by any great Personage." 84

Pozzo's work in the corridor is a pictorial homage to St. Ignatius, comprising a complex system of fictive architecture which frames a series of scenes of the saint's life and his "miracles" (Figure 3.4). These are based on biographical information as well as legends which glorify the saint and his qualities - much like the images devoted to St. Francis Xavier at Mondovì. The scenes along the walls concern the life and miracles of Ignatius, while the major panels of the

\footnotetext{
81 Lucas, "La Galleria del Pozzo," 141.

82 Lydia Salviucci Insolera, Andrea Pozzo e il Corridoio di S. Ignazio: Una "bellissima idea" (Rome: Artemide, 2014), 25-26.

83 Pascoli, "Di Andrea Pozzo," 693. See correspondence cited by Insolera in Andrea Pozzo e il Corridoio, 55-59.

84 Translation mine: "non sarebbe quasi più Corridore, ma come un bellissimo, e magnificentissimo Portico delle medesime Cappelle, che le renderebbe, e più nobile, e più venerabile. . . si rende questo luogo uno dei più belli Santuarij di Roma, degno d'essere ammirato, e riverito da qualsivoglia gran Personaggio." ARSI [Archivum Romanum Societatis Iesu], Rom. 144, fols. $303^{\mathrm{r}}-305^{\mathrm{v}}$, "Alcune Considerationi da ponderarsi bene, e molto maturamente intorno al fare, o non fare l'Ingresso delle Cappelle di S. Ignatio nel Corridore," transcr. Insolera, Andrea Pozzo e il Corridoio, 167-69.
} 
vault celebrate his place in heaven. ${ }^{85}$ The cycle might be regarded as a pictorial rendition, and summary, of the various biographical sources on Ignatius. ${ }^{86}$ The images are not arranged chronologically, and the scenes on the walls serve not as visual narratives of documented events, but rather as allegorical scenes of the saint as a heavenly intercessor on earth. The six miracles include, on the left wall, The Miracles of the Oil in the Lamp of St. Ignatius in the Grotto of Manresa, St. Ignatius Frees a Possessed Man, and An Angel Disguised as a Pilgrim Completes a Portrait of St. Ignatius; and on the right wall, St. Ignatius Appears to Prisoners and Comforts Them, St. Ignatius Appears to an Ill Nun and Cures Her, and St. Ignatius, Invoked by Prayers, Extinguishes a Fire. ${ }^{87}$ Pedro Ribadeneyra (1527-1611), the biographer who knew Ignatius personally, maintained that the saint never performed miracles in his lifetime. ${ }^{88}$ The miracle scenes we see in the corridor, as Evonne Levy explains, "were represented as types rather than specific historical instances," and their stories were largely the product of the widespread fervor for the saint after his beatification and subsequent canonization, rather than recorded history. ${ }^{89}$ Passing through this system of Ignatian imagery within in a space adjacent to the saint's rooms thus becomes an Ignatian pilgrimage.

The full rigor of Pozzo's perfected perspective method is demonstrated more clearly here than in any of his other fresco projects. On the walls and the vaulted ceiling of the corridor he produced an uncompromising perspectival construction based on a single viewing position. From the center of the room,

85 The scenes and iconography are discussed by Bernhard Kerber, Andrea Pozzo (Berlin: Walter de Gruyter and Co., 1971), 50-54; Pfeiffer, "Pozzo e la spiritualità della Compagnia di Gesù," in Andrea Pozzo, ed. Alberta Battisti, 13-31; and Insolera, Andrea Pozzo e il Corridoio, 67-97.

86 These include the illustrated biography by Nicholas Lancicius, S.J., Filippo Rinaldi, S.J., and Péter Pázmány, S.J. Vita Beati P. Ignatii Loiolae Societatis Iesu Fundatoris (Rome, 16og); Daniello Bartoli, De vita et instituto S. Ignatii Societatis Iesu fondatoris, trans. P. Ludovico Ianino (Lyon: Laurent Anisson, 1665); and Pedro Ribadeneyra, Vita Ignatii Loiolae (Lyon: Iacob Roussin, 1595; orig. 1583). Insolera claims that of the various editions by Bartoli, the revised edition of 1659 was probably the one Pozzo consulted. Insolera, Andrea Pozzo e il Corridoio, 21.

87 Evonne Levy, Propaganda and the Jesuit Baroque (Berkeley: University of California Press, 2004), 147-49. See also Insolera, Andrea Pozzo e il Corridoio, 73-81.

88 Ribadeneyra further underlined in his biography that miracles were not necessary proof of sanctity "Probatio sanctitatis non est signa facere." Ribadeneyra, Vita Ignatii Loiolae, 654.

89 Levy, Propaganda, 146. See also Insolera, Andrea Pozzo e il Corridoio, 145. 
he established a single vanishing point for each surface of the corridor: one at eye level on each of the walls, corresponding to the marked center of the room, and one directly overhead on the vault. ${ }^{90}$ Using these points to determine the perspective, he constructed the scene like he would any of his scenographic or architectural projects: he produced elevations for each surface based on the desired appearance of the whole, accounting for the respective viewing angles. He thus designed the illusionistic architecture and figures of the corridor as a totality: a complete viewing experience encompassing all directions of sight, which occurs at a single designated position in the space.

Applying this perspective system, Pozzo created, on the surface of the existing space, a new fictive architecture comprising pilasters with a projecting cornice, and above it a series of horizontal beams supported by projecting corbels (Figure 3.5). Between the beams the ceiling appears to rise and terminate in large coffers, which contain the major celestial scenes of the saint; while below, between the pilasters which support these beams, are the miracles of the saint drawn primarily from oral tradition. ${ }^{91}$ Suspended within this architectural system are groups of putti and angels engaged in celebration and holding various symbols associated with the saint. At the opposite end from where one enters, the space appears to open and continue into the curved space of a domed chapel with a portrait of the saint framed over an altar. Preceding the fictive chapel are two angel musicians playing a violin and viol da gamba under a two column-deep Serlian arch. This is what we see when standing on the marked geometric center of the corridor.

As we move away from the center in either direction, we find the beams overhead distort dramatically into arcs, the vertical corners of the coffers lean inward as the coffers gradually collapse, the pilasters become wider and seem to turn away from us, and the figures of the angels and putti elongate. We realize that the walls are a straight run of plaster, that the ceiling is a shallow barrel-vault, and that the spacious chapel at the end is a scene painted on a flat wall—a wall which runs at a pronounced angle (Figure 3.4). Pozzo's "architecture" is a perspectival construction rendered on five surfaces, which completely fills our range of vision, and optically changes the architectural form of the space. The figures which inhabit this space are rendered with varying degrees of distortion to account for the optical foreshortening produced by viewing them at an acute angle.

\footnotetext{
9o The question of how this perspective system in the corridor was achieved has been addressed in detail by Filippo Camerota in "Stimando per vero quel che è solo apparente': La costruzione prospettica del Corridoio," in Insolera, Andrea Pozzo e il Corridoio, 159-66. Insolera, Andrea Pozzo e il Corridoio, 145.
} 


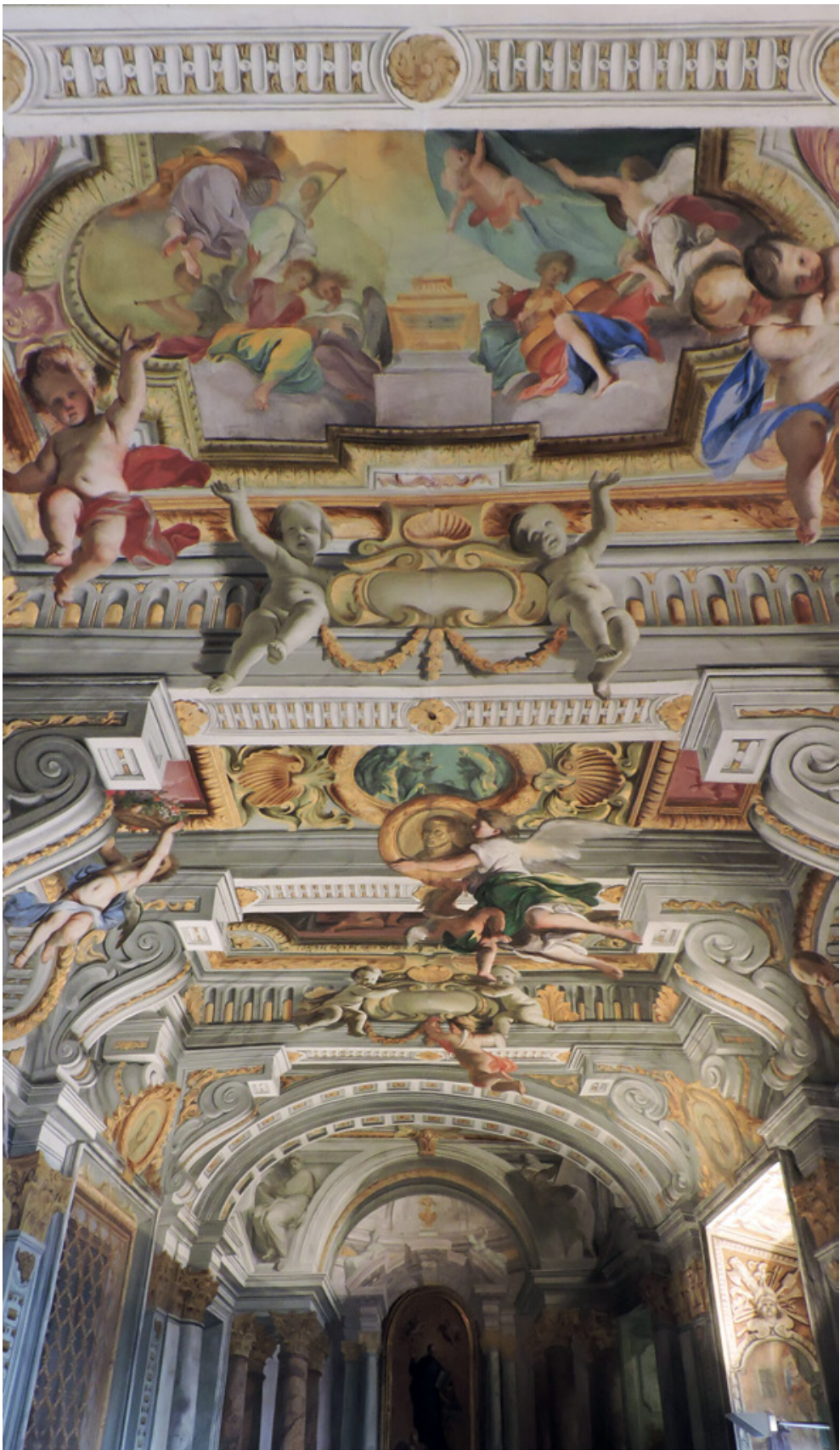

FIGURE 3.5 Andrea Pozzo, fresco cycle, Corridor of Saint Ignatius, c.1682-86. View from center toward chapel wall. Casa Professa del Gesù, Rome PHOTO BY THE AUTHOR 
We may note that the experience of the Corridor is decidedly different from that of San Francesco Saverio at Mondovì, with its multiple viewing positions. How do we reconcile Pozzo's choice of a single, fixed viewing position with the idea of the visitor's dynamic interaction with the perspectival images, moving through the space? In all of Pozzo's perspective projects, including the scenographies, the perspectival construction, the illusion, is intended to be discovered. This is a key aspect of the viewer's experience and of Pozzo's work, and it may be said to contain metaphors of its own. The theme of the deceit, the inganno, and subsequent revelation of the deception, the disinganno, appears as a cultural metaphor of the period, finding expression in literature, rhetoric, and, as we see in the work of Pozzo, art. ${ }^{92}$ This theme becomes central to the theory and discussions of perspectival illusionism by the early seventeenth century, as indicated by the title of Pietro Accolti's $(1578-1627)$ treatise of 1625 , Lo inganno degli occhi, prospettiva pratica..$^{93}$ It is also repeatedly raised within the text of Pozzo's own treatise. ${ }^{94}$ In his famous treatise on metaphor and symbol, Il cannocchiale aristotelico (1670), the Jesuit scholar of rhetoric and playwright Emanuele Tesauro (1592-1675) illustrates as one of his categories the "Metaphor of Deception," or of the "Unexpected."95

92 The Spanish equivalent, "engaño" and "desengaño," is a recurring theme in early modern Spanish literature; as demonstrated in the writing of Balthasar Gracián (1601-58) and Cervantes (1547-1616), it is frequently associated with the falsity of perceptions and of situations brought on by deceit. A few references among the substantial body of literary criticism that addresses the theme include Steven Wagschal, The Literature of Jealousy in the Age of Cervantes (Columbia, MO: University of Missouri Press, 2006), 23-26; and Jeremy Robbins, "From Baroque to Pre-Enlightenment: Resolving the Epistemological Crisis," Bulletin of Spanish Studies 82, no. 8 (2005): 225-53. In art historical studies, Emmanuelle Hénin indicates the psychological element of inganno in her definition of the term, which embraces two types of illusion: "the illusion contrived by the decor, and the illusion suffered by the spectator." Hénin, "Parrhasius and the Stage Curtain: Theatre, Metapainting and the Idea of Representation in the Seventeenth Century," in Theatricality in Early Modern Art and Architecture, ed. Caroline van Eck and Stijn Bussels (Hoboken: Wiley-Blackwell, 2011), 49-61, here 56 .

93 Pietro Accolti, Lo inganno de gl'occhi, prospettiva pratica (Florence: Pietro Cecconcelli, 1625).

94 Pozzo uses expressions meaning to trick-either "ingannare" or "gabare" - throughout both tomes of the treatise. He opens Perspectiva, I, with his address to the reader saying, "L'Arte della prospettiva con ammirabil diletto inganna il più accorto de' nostri sensi esteriori che è l'Occhio." See also the texts accompanying Perspectiva, I, figs. 6o, 66, and 101; and Perspectiva, II, fig. 47 .

95 Emanuele Tesauro, Il cannocchiale aristotelico, o sia idea dell'arguta et ingeniosa elocutione che serve à tutta l'arte oratoria, lapidaria, et simbolica (Turin: Zavatta, 1670), "Metafora ottava, di Decettione," 46o-61. 
He describes the experience as a "delight to the intellect," the delight of surprise: "It is therefore a secret and innate delight of the human intellect [...] because that transition from the inganno to the disinganno is a manner of learning by way of the unexpected."96 Tesauro's conception of the discovery of the "trick" is not merely the registering of surprise as an entertainment; it demonstrates a moral virtue: a certain intellectual agility and playfulness (he cites Aristotle's Eutrapelia) regarding both jokes and perceptual tricks, and the ability to derive pleasure from certain kinds of deception. ${ }^{97}$ Because Pozzo's perspectival images in the corridor are constructed based on a single viewing position, the illusion is already predisposed to be revealed on the first encounter. What is the intended result of the disinganno, the revelation of "truth," when the mask is pulled away? The discovery of the illusion calls into question perception itself, and our faith in our own senses. Where we go upon this discovery is the next step, one that has led to the many philosophical and theological interpretations of Pozzo's perspective system.98

The encounter with the artifice of painted illusion, and the recognition of it as artifice - the inganno and disinganno - is a virtue of the work reinforced by the words of Pozzo himself, who in his treatise defines perspective as a "counterfeiting of the truth": a construction and a fiction, not to be taken for reality.99 The disinganno is central to his work and its reading; and, we may say, its meaning. ${ }^{100}$ In her discussion of the perspective of the corridor Lydia Salviucci Insolera has highlighted the theme of Ignatian discernment as an essential component of Jesuit religious training. ${ }^{101}$ The central viewing position might be considered a metaphor for the point of discernment between the stable and

96 Translation mine. "Egli è dunque una segreta \& innata delitia dell'Intelletto humano, l'avvedersi di essere stato scherzevolmente ingannato: peroche quel trapasso dall inganno al disinganno, è una maniera d'imparamento, per via non aspettata; \& perciò piacevolissima." Tesauro, Il cannocchiale aristotelico, "Metafora Ottava, di Decettione," 460.

"tutte son DECETTIONI IN FATTO ò Facette Urbane, appertenenti à quella giocosa \& giocanda Virtù Morale, che il nostro Autore chiamò Eutrapelia: cioè versabilità d'intelletto, adattantesi al genio di coloro con cui lietamente conversa, \& passa il tempo." Tesauro, Il cannocchiale aristotelico, "Metafora ottava, di Decettione," 461. Tesauro cites Aristotle, Ethics, Chapter 8.

98 See, for example, Bernhard Kerber, "Pozzo e aristotelismo," Andrea Pozzo, ed. Battisti, $33-47$.

99 Pozzo, Rules and Examples of Perspective, Proper for Painters and Architects, trans. John James of Greenwich (London: B. Motte, 1707), "An Answer to the Objection made about the Point of Sight in Perspective."

100 For further discussions of Pozzo's deliberate disinganno, see Felix Burda-Stengel, Andrea Pozzo and Video Art, 79; and Insolera, Andrea Pozzo e il Corridoio, 150.

101 See Insolera, Andrea Pozzo e il Corridoio, 150 and Ignatius, The Spiritual Exercises, "Rules for the Discernment of Spirits." 
the unstable, the true and the false, the real and the illusory, the ephemeral and the "permanent," the vain and terrestrial and the eternal. ${ }^{102}$ The Corridor of Saint Ignatius, like all corridors, is a means of passage and therefore lends itself to forward progression; such a progression is not unlike that in which the visitor engages at Mondovi; or indeed the ritual procession associated with the celebration of a newly canonized saint. As one processes through the space, the perspective system, as a result of this movement, undergoes a transformation from "chaos" to "order."103 The unstable or unsettling quality of the perspective, together with the "stable" scenes of the saint's miracles, might be thus be read as a metaphor for Ignatius guiding the pilgrim along the correct path, miraculously intervening in the worldly disorder, ordering everything into a rational and stable system, granting peace to the mind and the soul.

I propose the corridor as another spiritual theatre: a place of performed pilgrimage. Within this theatre, the perspective system, the iconography, and the many cases of whimsy which we find particularly in the figures of angels and putti, all find their place in a performed intellectual and spiritual journey. ${ }^{104}$ This journey, this performance, is both internal and external, calling upon the arts of memory and imagination, as well as movement and action. ${ }^{105}$ To enter the corridor, one passes through Pozzo's painted architectural façade of the entrance wall, marked by a cartouche bearing the inscription, "Enter the small sacred rooms of Saint Ignatius, one time inhabitant, now patron."106 One proceeds along the corridor, observing the scenes and emblems of the saint on the walls and overhead, and watching the architecture gradually take form. The scenes of the saint's miracles on the left and right represent Ignatius as, in Heinrich W. Pfeiffer's words, "a mediator between heaven and earth," granting comfort to the suffering, healing the sick, intervening in crisis, etc. ${ }^{107}$ The painting cycle is anchored in the center with a portrait of the Holy Family on the left, while above is a chiaroscuro relief medallion depicting the death of the saint, flanked by his apotheosis in heaven and angel musicians glorifying his remains symbolized by an urn. Music is represented, and made almost "audible," by the

\footnotetext{
102 Insolera, Andrea Pozzo e il Corridoio, 150.

103 For a discussion of the experience of the moving observer in the corridor, see BurdaStengel, Andrea Pozzo and Video Art, 66-73.

104 See Insolera, Andrea Pozzo e il Corridoio, 118-19 and 143-49.

105 Insolera describes an "interior" movement coinciding with the "exterior" movement brought about by the perspective system, which she discusses in terms of perception and the imagination (Andrea Pozzo e il Corridoio, 149).

106 Translation mine from the Italian translation of Insolera of the Latin: "Ingredere aediculas olim incolae nunc patrono S. Ignatio sacras" (Andrea Pozzo e il Corridoio, 67).

107 Pfeiffer, "Pozzo e la spiritualità," 15.
} 
seated angel musicians playing under the arch leading to Pozzo's fictive chapel. These are two among a number of gesturing figures which are not merely decorative devices, but actually seem to inhabit the space, giving it life and movement. The most striking of these are the angels bearing portraits of Jesuit saints, thought to be St. Francis Xavier and St. Francisco de Borja: one, in blue and white, we find over the entrance, and the other in green and white, just before the fictive arch leading to the chapel.

The scenes on the walls and ceiling provide the means of visualizing and contemplating the life and virtues of the saint, and underscore the idea of the saint as a miracle-performing mediator in the world. As in the frescoes at Mondovi, the gestures and actions of the figures of angels and putti welcome and guide the visitor through this ritual performance, accompanied by the angel musicians. The procession through the corridor is remarkably similar to the processional movement at Mondovì, while the cycle itself is much more articulated in its narrative and allegorical representation of the saint. Here, as at Mondovì, Pozzo chose to divide the space into small panels and perspective "openings"; and, as at Mondovì, the corridor terminates with a fictive altar, rendered entirely as a painted illusion, like a theatrical backdrop. Pozzo has done in Rome for Ignatius what he had done at Mondovi for Francis Xavier, celebrating the saint with images that combine biographical narrative, legend, and symbol, much like we find in canonization festivals of the period. ${ }^{108}$ The overall atmosphere is one of welcoming and celebration, with the angel musicians lending the corridor a particularly light-hearted quality. ${ }^{109}$

The corridor stands among the most remarkable of Pozzo's fresco cycles, a fully-integrated environment of fictive architecture and anamorphic figure painting which, like the cycle at Mondovì, both transforms the space and beckons the visitor along a path of discovery. The ensemble of images engages one in the performance of a processional-like meditation on the life and qualities of St. Ignatius of Loyola, which lay and religious alike are encouraged to emulate. Although smaller in scale than the expansive fresco project Pozzo had

108 In addition to the elaborate festival for St. Ignatius and St. Francis Xavier of 1622 described earlier, Milanese examples from later in the century which Pozzo would have witnessed include the festival for the Canonization of San Gaetano of the Theatines, recounted in Giovanni Battista Orrigone, Descrittione dell'apparato e feste solenni fatte a Milano ali 7 d'Agosto 1671: Da PP. Chierici Regolari, nella loro Chiesa di Sant'Antonio, in occasione della Canonizzazione di S. Gaetano Thiene, loro fondatore, e patriarca (Milan: Ludovico Monza, 1671).

109 Insolera describes the overall effect the whole, one of levity, movement and "musicality," as representation of Ignatian "spiritual joyfulness." Insolera, Andrea Pozzo e il Corridoio, $147-48$. 
executed at Mondovi, the corridor was of clear symbolic significance to the Jesuits, intimately associated with the rooms in which the founding saint had lived and died. The great apotheosis of St. Ignatius would await its most monumental treatment in Sant'Ignazio, where Pozzo produced the grandest of all visual statements concerning both the saint and the order he founded.

Jesuit theatre of the seventeenth century should be considered in the widest sense to include both ephemeral events and performances and their associated scenographies, and permanent works of art and architecture commissioned by the Society, in which a ritual performance takes place. If we consider performance as a defining feature of Jesuit religious and visual culture, we can say that it begins with the form of prayer exemplified by Ignatius's Spiritual Exercises, and takes its most concrete form in Jesuit theatre. This theatre includes not only theatrical performances, but also liturgy, religious devotions and festivals in which the Society was directly involved. All of these rituals featured images and scenography as essential components of a larger system which involved the performative participation of the public. The broader definition of Jesuit theatre which I have sought to illustrate here comprises visual rhetoric and ritual performance functioning together to produce a rhetorical system whose effectiveness depends upon the active involvement of the observer as a performer. Andrea Pozzo's major works-from his early scenographic projects to his fresco cycles, his altars and his grand Quarant'ore scenographies in Rome-are among the finest examples of Jesuit theatres in their conception and in their production. In confronting both the ephemeral and the permanent works of Pozzo within the constructed contexts of the religious buildings they adorn, and within the ritual contexts for which they were made, the observer engages in an internal and external performance. This performance includes movement in the space, involvement in the narrative of the painted scenes, spiritual reflection on their meanings, visual and intellectual engagement in the perspective systems and the spatial illusions they produce, and participation in the rituals for which they served an important practical and rhetorical function. Far from being merely a subject of literary or historical study, "Jesuit theatre" lives on in the continued engagement of observersas-performers with Jesuit works of art and architecture. 